\title{
Article
}

\section{The Impact of Coastal Geodynamic Processes on the Distribution of Trace Metal Content in Sandy Beach Sediments, South-Eastern Baltic Sea Coast (Lithuania)}

\author{
Dovilè Karlonienè $^{1, *}$, Donatas Pupienis ${ }^{1,2} \mathbb{D}$, Darius Jarmalavičius ${ }^{2}$, Aira Dubikaltinienè ${ }^{1}$ and \\ Gintautas Žilinskas ${ }^{2}$
}

Citation: Karlonienè, D.; Pupienis, D.; Jarmalavičius, D.; Dubikaltinienè, A.; Žilinskas, G. The Impact of

Coastal Geodynamic Processes on the Distribution of Trace Metal Content in Sandy Beach Sediments,

South-Eastern Baltic Sea Coast

(Lithuania). Appl. Sci. 2021, 11, 1106.

https://doi.org/10.3390/app11031106

Academic Editor: Mauro Marini

Received: 29 December 2020

Accepted: 20 January 2021

Published: 25 January 2021

Publisher's Note: MDPI stays neutral with regard to jurisdictional claims in published maps and institutional affiliations.

Copyright: (c) 2021 by the authors. Licensee MDPI, Basel, Switzerland. This article is an open access article distributed under the terms and conditions of the Creative Commons Attribution (CC BY) license (https:/ / creativecommons.org/licenses/by/ $4.0 /)$.
1 Faculty of Chemistry and Geosciences, Naugarduko st. 24, LT 03225 Vilnius, Lithuania; donatas.pupienis@gamtc.lt (D.P.); aira.dubikaltiniene@chgf.vu.lt (A.D.)

2 Nature Research Centre, Akademijos st. 2, LT 08412 Vilnius, Lithuania; darius.jarmalavicius@gamtc.lt (D.J.); gintautas.zilinskas@gamtc.lt (G.Ž.)

* Correspondence: dovile.karloniene@chgf.vu.lt

Featured Application: Geochemical analysis can provide valuable information about the local and regional patterns of sediment transport, distribution, provenance, and coasts' conditions.

Abstract: Sandy coasts are one of the most dynamic spheres; continuously changing due to natural processes (severe weather and rising water levels) and human activities (coastal protection or port construction). Coastal geodynamic processes lead to beach sediment erosion or accumulation. The coast's dynamic tendencies determine the changes in the volume of beach sediments; grain size; mineralogical; and geochemical composition of sediments. In addition to lithological and mineralogical analysis of sediments, geochemical analysis can provide valuable information about the local and regional patterns of sediment transport, distribution, provenance, and coasts' conditions. The study aims to assess trace metals' temporal and spatial distribution determined in the sandy beach sediments along the south-eastern Baltic Sea coast (Lithuania) during 2011-2018. The Lithuanian seacoast is divided into two parts: mainland and spit coast. Our results revealed that the dominant group of elements on the mainland includes $\mathrm{Ca}-\mathrm{Mg}-\mathrm{Mn}-\mathrm{Ti}$ and on the Curonian $\mathrm{Spit} \mathrm{Fe}-\mathrm{Pb}-\mathrm{As}-\mathrm{Co}-$ $\mathrm{Cr}-\mathrm{Ni}-\mathrm{Al}$, which remain unchanged during the years. The analysis included additional parameters such as beach volume, grain size and sorting, and heavy mineral concentration on the beach. The spatial analysis of trace elements indicated that the trace metal content depends on the coastal processes, but it differs in the mainland and spit sea coast. We identified a higher concentration of trace metals in the erosion-dominated areas in all analysed years on the mainland coast. On the spit coast, the trace metal concentration increased in areas associated with relict coarse sand and where the loading of sediments was active on the beach due to the northward along-shore transport.

Keywords: trace metals; beach sediments; coastal processes; lithology

\section{Introduction}

Trace metals enter the coastal system from the entire Baltic Sea catchment area, which is four times larger than the sea area. The main sources of trace metals besides natural ones in this area are the combustion of fossil fuels (transport and energy production), municipal and industrial sewage management, agriculture, manufacturing processes (pulp and paper, metallurgy, etc.), and military activities (chemical ammunition buried after World War II) [1]. These metals are transported to the sea and coastal areas by rivers, deposited from the air along with precipitation and other pathways.

Sandy beaches are considered important recreational sites and less recognised as highly threatened and fragile natural ecosystems, which may work as natural barriers to pollutants transported by sea [2,3]. Approximately, 50\% of coastlines globally are composed 
of sand and gravel, mostly due to river and land sediment transport and deposition [4]. However, the ultimate magnitude of the accumulation/erosion of beach sediments depends also on anthropogenic activities [5]. The textural, lithological, and mineralogical composition of beach sediments depend on many factors: the physical and geographical conditions of the location [6-8], geological framework [9-12], tectonic settings [13-17], provenance [18-22], climate and sea hydrodynamics (waves, tides, and currents) conditions [13,23-27], and the anthropogenic activities [27-31]. Sandy beaches are presently threatened by several forms of environmental degradation, although beach management has traditionally concentrated on geomorphic hazards [32] and recreational use of coast [33], while trace metals are rarely considered [34]. The geochemical analysis of beach sediments together with lithological and mineralogical characterisation can provide valuable information about the local and regional patterns of sediment transport, distribution, and provenance, as well as the conditions of the coast [35].

Global studies related to trace elements analysis on beaches focus on assessing the changes in trace element concentrations in the context of the influence of local pollution sources such as mining sites, urban areas, and industrial complexes [28,29,36-38] or tourism [39-41]. Several studies analysing the migration and distribution of trace elements in coastal environments have been conducted; e.g., the distribution of trace elements concentrations across (from the beach to dunes) [42] and along the coast [38,43-48] and vertical migration [49]. All overviewed studies intended to identify the source or how the particular pollution source affects beach sediments, but the coastal processes were not deeply analysed. The concentration of elements can be affected, as it is known in heavy minerals, by changes in the hydrometeorological conditions [23] or by the season [35,49]. The dominant coastal processes could affect the accumulation of trace elements, which could be of natural origin.

In Lithuania, the formation and dynamics of recent beach sediments have been analysed using lithological, mineralogical, morphometric, and other methods [12,27,50,51]. The nearshore mineralogical and geochemical composition of the Baltic Sea's Lithuanian territorial waters and distribution has already been well analysed $[21,52,53]$. However, the detailed geochemical composition of beach sediments in relation to active coastal processes has not been previously investigated, except for some local studies [54,55]. This study aims to assess the temporal change of the trace metal content in sandy beach sediments and the dependence on coastal lithomorphodynamical processes.

\section{Study Area}

The Lithuanian coast is divided by the $1.1 \mathrm{~km}$ wide Klaipeda Strait, where Klaipedda Port is located into two parts: the Curonian Spit (hereinafter-the spit) sea coast $(51 \mathrm{~km})$ and the mainland coast (39 km) (Figure 1). Beyond 1991, when the Curonian Spit National and Seaside Regional Parks were established, the major part of the Baltic Sea coast in Lithuania (about $70 \mathrm{~km}$ long) has acquired the status of a protected area. Several coastal sectors with different characters can be distinguished: a technogenic coast that predominates near to Klaipeda and Šventoji Ports, i.e., areas of waste water disposal from the Būtingè oil terminal, and the Mažeikiai oil processing plant, and protected areas such as the Curonian Spit National Park, the Seaside Regional Park, the Baltic Sea Talasological Reserve, and the Būtingè Geomorphological Reserve (Figure 1). 


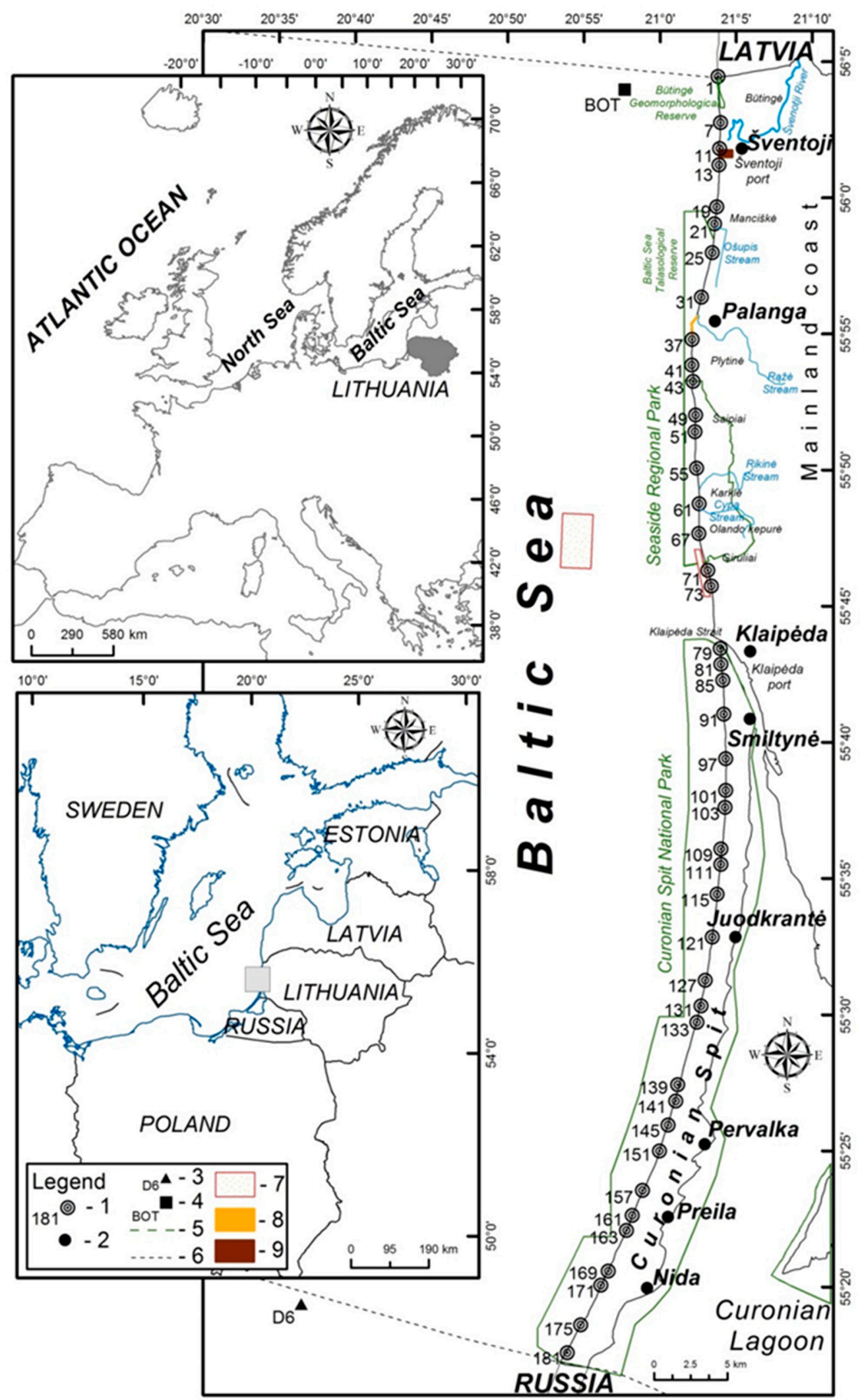

Figure 1. Study area. (1) surface sand sampling site, (2) main settlements, (3) D6 oil platform (Ru), (4) Būtingè oil terminal, (5) conservation areas, (6) borders, (7) offshore and nearshore dumping area, (8) beach nourishment site in Palanga, and (9) storage site of dredged bottom sediments. 
The Holocene clastic deposits occur along the entire length of the Lithuanian coastal zone. The Lithuanian coastal sediments are composed of quartz, K-feldspar (orthoclase, microcline), plagioclase (albite, anorthite), carbonates (dolomite, calcite), mica (biotite, muscovite), and clay minerals (illite, chlorite, kaolinite, montmorillonite, glauconite, and vermiculite) with admixture of heavy minerals [21,50].

On the mainland coast, the average $20-100 \mathrm{~m}$ wide beaches are backed by foredunes 4-12 $\mathrm{m}$ in height or by moraine cliffs 5-24 $\mathrm{m}$ in height. The southern part of the mainland coast structure between the 25th and 31st $\mathrm{km}$ (distance from Latvia-Lithuania border) is characterised by glacial (moraine) deposits formed during the Late Pleistocene and that, in most cases, occur on the abraded cliff coast. The first moraine cliff is located between the 25th and 27th km on the mainland coast near Šaipiai (Figure 1). The cliff is $2.1 \mathrm{~km}$ long and $5-8 \mathrm{~m}$ in height. The second moraine cliff (Olando kepurè) is $950 \mathrm{~m}$ long and $24 \mathrm{~m}$ in height at its highest point [56]. The highest cliffs are between the 30th and 31st $\mathrm{km}$ at Karklè. On the Curonian spit sea coast, the average width of the beaches varies from 32 to $75 \mathrm{~m}$, and the relative height of the foredune changes from 5 to $16 \mathrm{~m}$ [12].

The Baltic Sea is nontidal (amplitudes reach 3.5-4.0 cm); therefore, a wind-wave regime dominates. The cold (autumn-winter) season is marked by most days with strong winds. The annual mean wind speed is $4.7 \mathrm{~m} \mathrm{~s}^{-1}$ and the wave height is $0.65 \mathrm{~m}$. During the strongest storms, the wave height varies from 5 to $6 \mathrm{~m}$ [56]. The prevailing westerly (SW, $\mathrm{W}, \mathrm{NW}$ ) winds and waves are dominant in the coastal zone and generate the alongshore sediment transport from the Sambian Peninsula to the end of the Curonian Spit and along the mainland coast $[24,27,57]$. Currently, the alongshore sediment transport is disrupted by the Klaipeda port gate [58].

\section{Materials and Methods}

In the analysis, we focus on trace elements which are considered of anthropogenic origin. The macroelements, lithological and morphological parameters are used for the data interpretation and definition of the causes.

Sediment samples were collected along the entire Baltic Sea coast of Lithuania in 2011, 2014, and 2018 (Figure 1). During the collection of samples, the sea and wind conditions were relatively constant. In the coastal zone, the most active processes occurred in the surf and swash zone; for that reason, it was decided to take samples from the middle of the beach [26]. Totally, 43 composite surface sand $(0-5 \mathrm{~cm})$ (from 5 subpoints) samples were collected at equal distances of 3 and $5 \mathrm{~km}$ and in plastic containers delivered for laboratory analysis [27]. In the laboratory, sand samples were air-dried and split to $100 \mathrm{~g}$ of sediment. The samples were mechanically sieved $15 \mathrm{~min}$ on a vibratory sieve shaker Fritsch Analysette 3 Spartan Pulverisette 0 using a set of 11 sieves. After determination of size fraction, statistical grain-size Falk and Ward method mean $(\mathrm{d}, \mathrm{mm})$, sorting $\left(S_{0}\right)$ parameters were calculated using the GRADISTAT 8.0 software [59].

To characterize the relative concentrations of heavy minerals, a Bartington MS3 field scanning sensor was used for rapid and effective measurements of low-field volume magnetic susceptibility [27]. Sandgren and Snowball [60] point out that bulk magnetic susceptibility (MS) is a good indicator of allochthonous mineral matter in sediments. Measuring MS helps to determine the net contribution of ferromagnetic and paramagnetic minerals in sediments. Heavy mineral-rich $\left(\rho>2.90 \mathrm{~g} / \mathrm{cm}^{3}\right)$ sediments have ferromagnetic and paramagnetic properties, and high magnetic susceptibility values, depending on the predominant iron content. Quartz-rich minerals $\left(\rho<2.65 \mathrm{~g} / \mathrm{cm}^{3}\right)$ have diamagnetic properties. Quartz-rich sands (dominate quartz, feldspar, carbonate, and mica group minerals) have weaker positive magnetic susceptibilities values of $\kappa<3.0 \mu \mathrm{SI}$, heavy mineral-rich sand (elements like $\mathrm{Ti}, \mathrm{Cr}, \mathrm{Mn}, \mathrm{Fe}, \mathrm{Co}, \mathrm{Ni}$, and $\mathrm{Cu}$ can sometimes result in magnetism) $\mathrm{k}$ values range from 30 to $150 \mu \mathrm{SI}$ and higher values $\mathrm{k}>150 \mu \mathrm{SI}$ are typical for heavy minerals with $\mathrm{Fe}, \mathrm{Ni}$, and Co elements [26,61,62]. MS measurement method is helpful to detect ferromagnetic minerals when their concentration in sediments is deficient [60]. Magnetic susceptibility and grain sizes of beach sediments belongs of the provenance, 
geologic framework, alongshore sediment transport, deposition and coastal processes (erosion/accretion), etc. The grain size composition also might have contributed to the difference in proportions of ferromagnetic, paramagnetic, and diamagnetic minerals [63]. Magnetic minerals are known as important sources of trace elements in sediments.

The beach sediment volume $\left(Q, \mathrm{~m}^{3} / \mathrm{m}\right)$ was calculated for each profile based on repeated cross-shore levelling once per year. The changes in sediment volume comprise the changes in volume of the coastal profile from the foredune lee side, where the vertical variability is negligible during observation, to the intersection with the mean sea level [12]. Total beach sediment volume was counted with the formula: $Q=\left(Q_{i}+Q_{i}+1\right) L_{i} / 2$, where $Q$-sediment volume $\left(\mathrm{m}^{3}\right)$ at the coastal segment; $i=1,2,3, \ldots$ number of transects; $Q_{i}$-sediment volume at the separate coastal cross-section profile $\left(\mathrm{m}^{3} / \mathrm{m}\right)$; and $L_{i}$-distance between levelling cross-section profile lines [64].

For the geochemical analysis, the dried samples were ground using an agate mortar and pestle. Prior to each sample's homogenisation, the agate mortar and pestle were washed with deionised water and dried twice. Geochemical analyses of the samples were performed at the Bureau Veritas Commodities Canada Ltd., laboratory. 0.5-2.0 g of bulk sample digested after application of modified aqua regia $\left(1: 1 \mathrm{HNO}_{3}: \mathrm{HCl}\right)$ solution for low to ultralow determination of soil and analysed with an inductively coupled plasma mass/emission spectrometer (ICP-MS/ES). In this study, we mostly analysed trace elements that might originate from the anthropogenic activities common in coastal systems as fossil fuel burning, sewage discharge, metals common in ship ports, etc. and monitored at the national monitoring program [65]. We also selected macroelements that could help to describe the origin of sediments. The results are given in ppm for elements $\mathrm{As}, \mathrm{Cu}, \mathrm{Cr}, \mathrm{Co}$, $\mathrm{Mn}, \mathrm{Ni}, \mathrm{Pb}$, and $\mathrm{Zn}$; in ppb for $\mathrm{Hg}$; and in percentage for $\mathrm{Ca}, \mathrm{Mg}, \mathrm{Fe}, \mathrm{Al}$, and Ti. Analytical quality was monitored in each batch of samples by repeated analyses, recovery of spiked samples, and analysis of a certified reference material (OREAS45EA and DS11), and duplicates and blanks were used to assure the quality of the analysis. The reaction mixture was chosen to evaluate the labile trace elements dissolving sulphide/oxide type minerals to exclude the elements incorporated in the silicate lattice as metals from anthropogenic sources tend to be more mobile than those from pedogenic or lithogenic sources [43,66].

Descriptive and multivariate statistical methods were applied to analyse the results. Correlation analysis using Pearson's coefficient (linear relation, significant $p>0.01$ or 0.05 ) and principal component analysis (PCA) were applied to transform the correlation matrix to identify the relationship between the metals [31]. For the PCA analysis, we used the Varimax rotation method to derive more reliable information on the distribution of the weights of the variables on a factor, and loadings higher than 0.5 were considered. Statistical programs IBM SPSS Statistics 22.0 and PAST 3.24 were used.

The concentration of trace metal in each site was compared with the median estimated of all samples at that year $K_{k}=\left(K_{n}\right) /\left(M_{n}\right)$, where $K_{n}$-concentration of the element $n$ and $M_{n}$-the median concentration of the element $n$. Median presents the central or typical value in a set of data and is weakly dependent on minimal and maximal values and outliers, this approach has been used and developed in a few studies [48,52,67]. This analysis helps to compare the loading of analysed elements among sites; the lower limit of the anomaly is considered as 1.5 [52]. Following a multi-element index, the integrating and averaging data were estimated, $K_{d}=\Sigma K_{k} / n$, where $K_{k}$-is the concentration ratio for a specific element and $n$-number of elements. We assumed that $K_{d}$ values higher than 2 indicate an anomaly concentration in the site [68].

Other studies use concentration ratios to determine trace element accumulation in sediments and focus on anthropogenic pollution [43,53,69-71], the determination of background concentrations in such studies is essential [71]. The main concept to identify the anthropogenic impact is to compare the concentrations of elements measured in uncontaminated sites-to establish a local baseline or, as in most studies, compare sediment element concentrations with preindustrial levels such as average shale [72] or average crustal value [73]. Using the average shale or earth's crust concentrations, the local geo- 
chemical framework is being ignored, which might lead to misinterpretation of anomaly concentrations in the analysed region. Second, the shale concentration mostly represents fine grain sediments and earth's crust—coarse sediments, meanwhile the background concentration represents sites in similar mineralogical and textural environments [71]. In this study, we analysed beach sand, dynamic environment and usage of shale or earth's crust as the background concentration might miss an important pattern in the distribution of trace elements. For that reason, we chose to use the values calculated during our study. We also considered the values as a background—calculated from 76 samples of aeolian sediments collected in the western region of Lithuania located close to our studied area [74]. However, this area is remote from the sea-where the sediments are affected by both wind and water; thus, we considered not to apply these data in the current study.

\section{Results}

\subsection{The Lithology of Beaches}

The sandy beaches on the Lithuanian sea coast are composed of fine-medium grain sediments $(d=0.27 \mathrm{~mm}, \sigma=0.07$ in $2011 ; d=0.29 \mathrm{~mm}, \sigma=0.09$ in $2014 ; d=0.29 \mathrm{~mm}$, $\sigma=0.11$ in 2018). Although in 2011, fine and medium sand predominated on the beaches, in 2014 and 2018, coarse sand was already detected in several places (Figure 2). In 2011, fine sand dominated in 23 and medium sand in 20 sites. In 2014, fine sand was determined in 20 sites, the medium - dominated in 21 places, and coarse sand - in two sites-73rd and 131st. In 2018, fine sand was indicated as well in 21 places, medium sand in 19 places, and coarse sand in 3 places-61st, 73rd, and 133rd. The appearance of coarse sand at Olando kepure, north of Klaipeda port pier, is related to the intensified local erosion processes. Erosive processes are local and usually occur in specific stretches of the coast, e.g., where moraine cliffs predominate, or are affected by hydrotechnical construction.

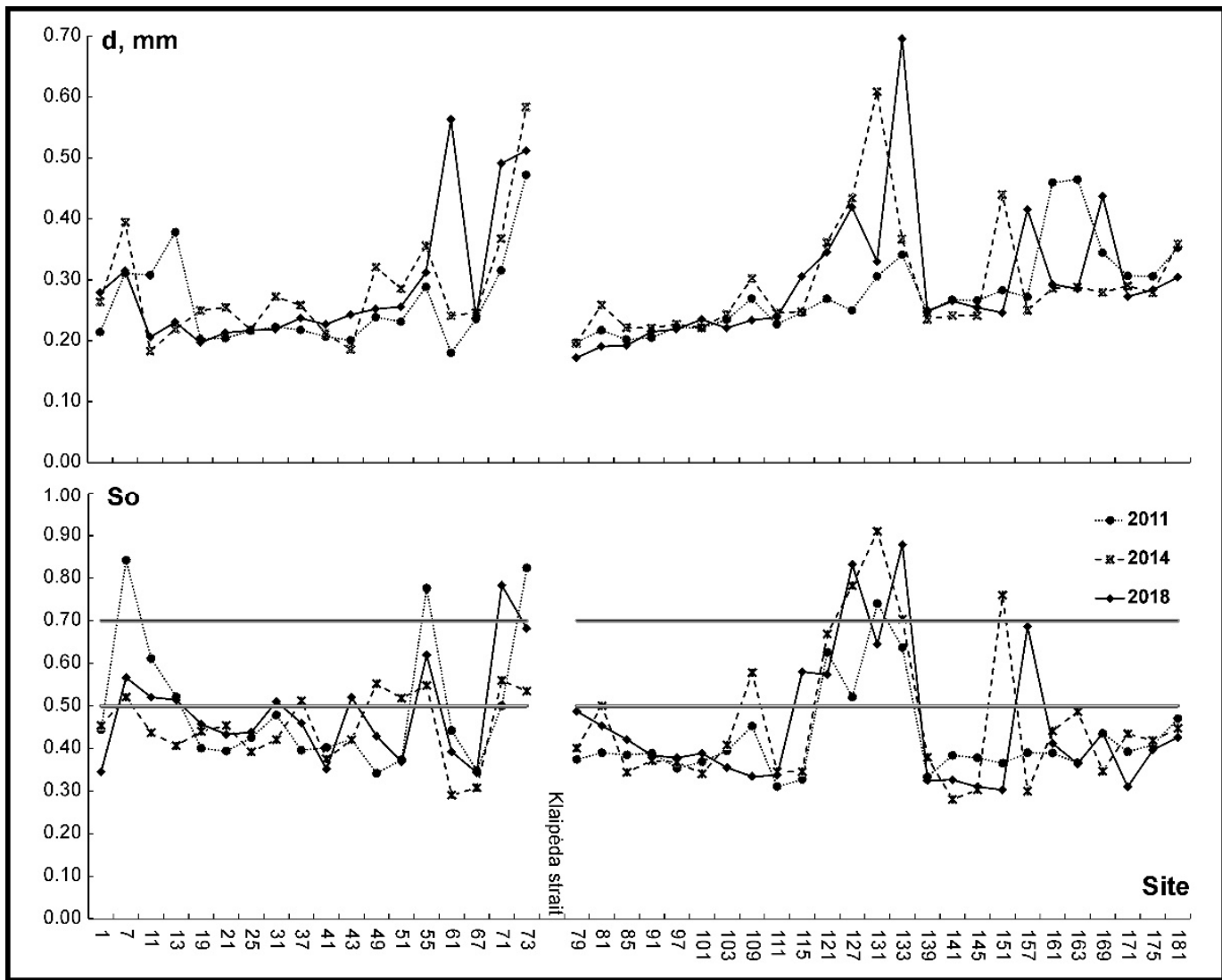

Figure 2. The distribution of grain-size $(\mathrm{d}, \mathrm{mm})$ and sorting $\left(S_{0}\right)$ of the beach sediments along the coast of the south-eastern Baltic Sea coast (Lithuania) in 2011, 2014, and 2018. 
In all investigated years, the surface sand on the mid-beach was very well sorted $\left(S_{o}<0.35\right)$ and well sorted $\left(0.35<S_{0}>0.50\right)$ (Figure 2). Moderately well-sorted $\left(0.50<S_{0}>0.70\right)$ or moderately sorted $\left(S_{o}>0.70\right)$ sand was in areas with a medium or coarse sediment fraction. In 2011, moderately sorted sand was identified in 9; in 2014 -in 13, and in 2018 -in 14 sites. The distribution of beach sand particles shows that the average particle diameter decreases from south to north on both the mainland and the Curonian Spit coast (Figure 2).

\subsection{Magnetic Susceptibility of Beach Sediments}

The bulk MS values of the sediments on the investigated coast ranged between 13.9 and 357.7 $\mu$ SI (mean $\kappa=64.4, \sigma=58.7)$ in 2011, between 16.5 and $804.8 \mu S I$ (mean $\kappa=139.1$, $\sigma=161.6$ ) in 2014, and between 7.9 and $271.8 \mu$ SI (mean $\kappa=77.7, \sigma=60.2$ ) in 2018 (Figure 3). The MS values differed between the mainland and Curonian Spit coast, i.e., in 2011 and 2014, the MS values measured higher on the mainland coast, and in 2018, the difference in the values faded. The anomalous MS values were determined at the $7 \mathrm{th}, 21 \mathrm{st}, 127 \mathrm{th}$, and 181st.

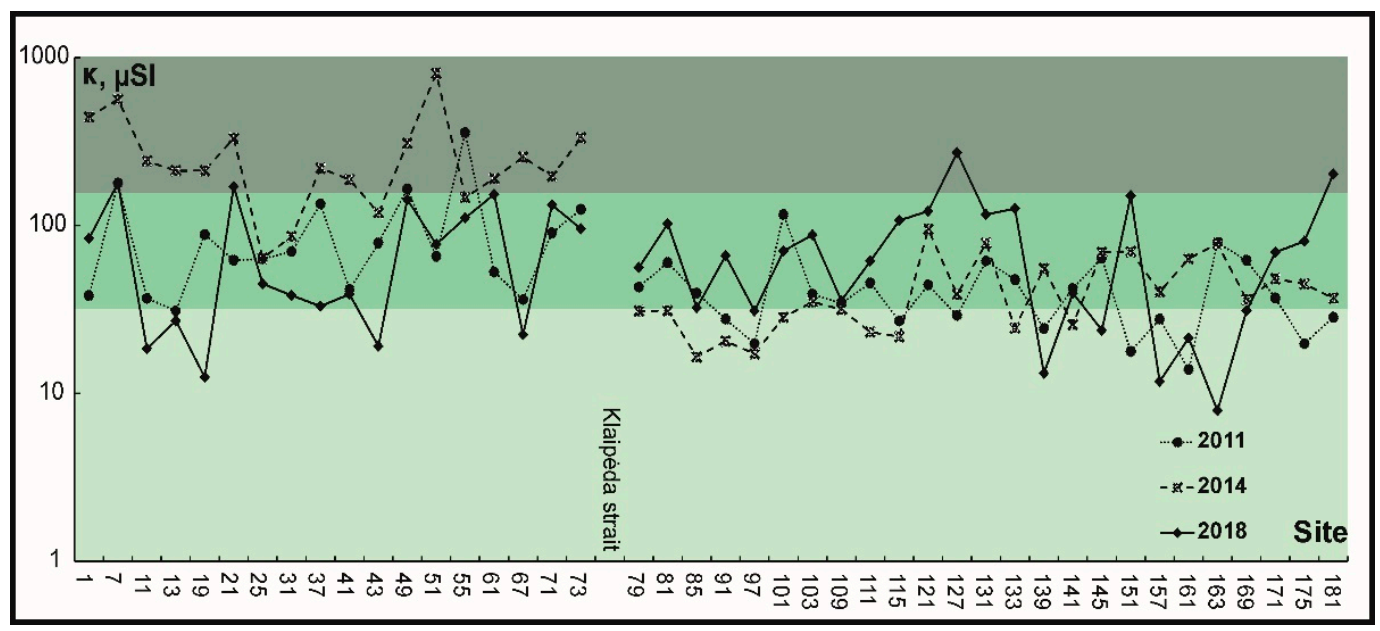

Figure 3. The distribution of magnetic susceptibility values $(\kappa, \mu \mathrm{SI})$ of the beach sediments along the coast of the southeastern Baltic Sea coast (Lithuania) in 2011, 2014, and 2018 (the dark green colour field indicate heavy minerals, green-heavy mineral-rich sand and light green-quartz-rich sands).

The MS values differed between the mainland and Curonian Spit coast. In 2011 and 2014, the MS values were higher on the mainland coast, and in 2018, the difference in the values faded. The higher values of magnetic susceptibility were detected in the beach sediments, enriched with perimagnetic and ferromagnetic minerals. The anomalous MS values were determined at the 7th, 21st, 127th, and 181st. Magnetic susceptibility reflects different coastal processes and magnetic mineral sources. Magnetic susceptibility of beach sediments increases greatly close to the provenance and decreases moving away from source.

\subsection{Beach Sediment Volume}

The beach sand volume $\left(Q, \mathrm{~m}^{3} / \mathrm{m}\right)$ compared between 2011 and 2014 increased by in almost all sites on the mainland coast except in the 25th, 41st, and 49th (Figure 4). However, on the Curonian Spit coast, the sediment content on the beaches in 2014 compared to 2011 decreased in the end of the spit (79th and 91st-109th) and in Juodkrante-Pervalka section (115th, 127th, 133rd, 139th), higher in the 141st, 161st, and 175th sites, the highest increase in sediments was in the south of Nida (157th, 169th, 171st, and 181st). 


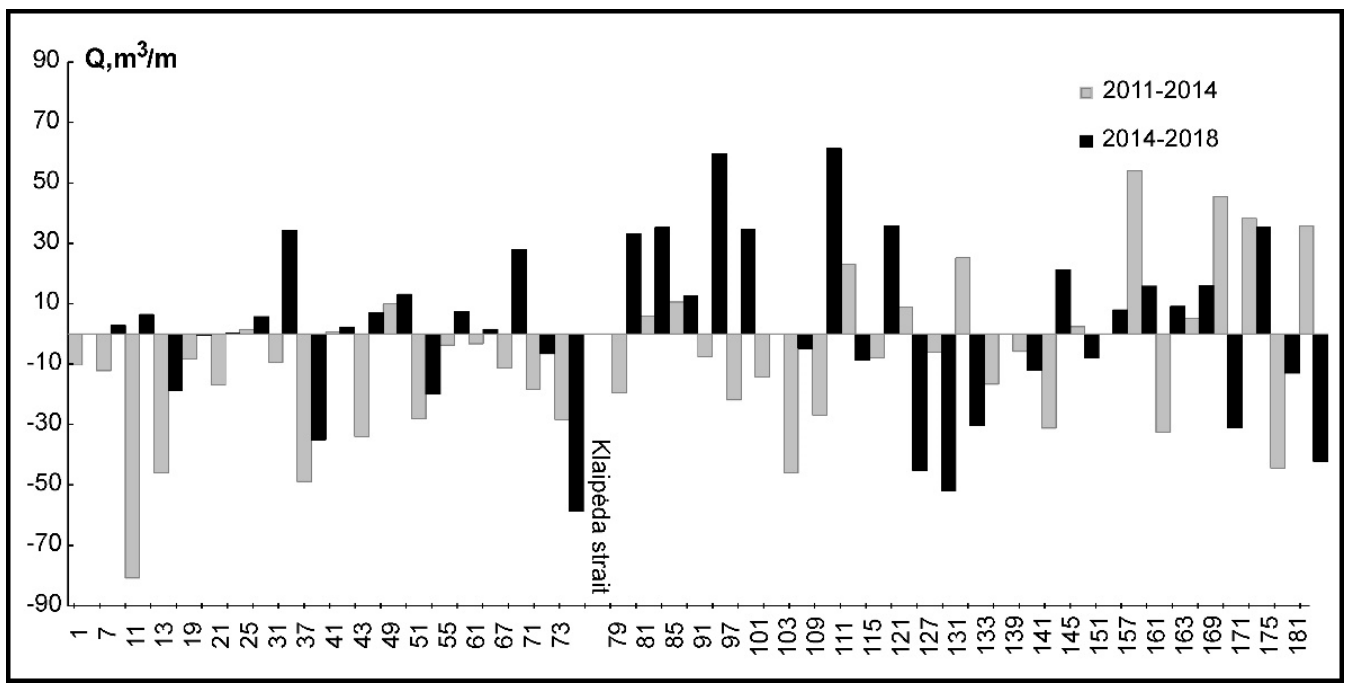

Figure 4. The changes in beach sediment volume $\left(Q, \mathrm{~m}^{3} / \mathrm{m}\right)$ distribution along the coast of the south-eastern Baltic Sea coast (Lithuania) in 2011, 2014, and 2018.

Comparing 2018 and 2014 sediment volume on the beaches, on the mainland coast the highest increase was determined in the 31st, 49th, and 61st, and the significant decrease was determined in the 13th, 37th, and 51st sites, but mostly in the 73rd. On the Curonian Spit coast, the sediment volume increased mostly at the end of the Curonian Spit (79th-97th, 109th, 115th) and 141st. The considerable decrease in sediments on the beaches of the spit was estimated on Juodkrantè-Pervalka (121st, 127th, 131st), 169th, and 181st sites.

\subsection{Descriptive Statistics of Trace Elements}

The descriptive statistics for the 3 years of the analysed trace elements $(\mathrm{Cu}, \mathrm{Pb}, \mathrm{Zn}, \mathrm{Ni}$, $\mathrm{Co}, \mathrm{Mn}, \mathrm{As}, \mathrm{Cr}, \mathrm{Hg}$, and $\mathrm{Cd}$ ) and macroelements ( $\mathrm{Fe}, \mathrm{Al}, \mathrm{Ca}, \mathrm{Mg}$, and $\mathrm{Ti}$ ) are provided in Table 1.

The comparison of the average concentrations of the trace elements in the analysed years revealed that the higher average concentrations of most elements were measured in 2014. In 2011, the higher concentrations of As and Cr compared to other years were determined, while in 2018, only for Mn. Additionally, in 2014, $\mathrm{Hg}$ was measured in sediments collected on 18 sites; in 2011, Hg was detected only on eight sites; and in 2018, $\mathrm{Hg}$ was found on six sites.

\subsection{Distribution of Trace Elements Along Coast}

We assessed the distribution of the average concentration of trace elements and the medium value ratio $\left(K_{k}\right)$ along the coast. The pattern of the ratio differed among elements. The $K_{k}$ of As were estimated only on the Curonian Spit coast where the ratio exceeded 1.5 in six sites on the distal end of the spit (79th, 85th, and 103rd-111st) and Pervalka-Preila section (145th) in 2011, in four sites (109th, 111th, 131st and 145th) in 2014, and in only one Juodkranté-Pervalka section (133rd) in 2018. We estimated higher than $1.5 \mathrm{Kk}$ values for $\mathrm{Cr}$ in 2011 in seven places, a significant majority at the distal end of the Curonian Spit (79th-111th); in 2014, already in 12 sites (79th, 91st, 111th, 131st, 145th, 157th, 171st, and 175th), and only in one site (51st) on the mainland coast (Figure 4). In 2018, as in previous years, we indicated the highest $\mathrm{Cr}$ concentration at the distal end of Curonian Spit (79th-109th) and in the coast stretch southern from Juodkrante (133rd, 139th, 145th, 151st, and 181st) (Figure 5). 
Table 1. Trace element concentrations of the surface sediments collected on the beach along the coast of the south-eastern Baltic Sea coast (Lithuania) in 2011-2018 (values in ppm unless otherwise indicated).

\begin{tabular}{|c|c|c|c|c|c|c|}
\hline Element & Year & $\mathbf{N}$ & Mean & $\sigma$ & Median & $\operatorname{Min}-\operatorname{Max}$ \\
\hline \multirow{3}{*}{$\mathrm{Cu}$} & 2011 & 42 & 0.32 & 0.13 & 0.30 & $0.17-0.70$ \\
\hline & 2014 & 43 & 0.77 & 1.01 & 0.40 & $0.16-4.15$ \\
\hline & 2018 & 42 & 0.44 & 0.54 & 0.28 & $0.14-3.10$ \\
\hline \multirow{3}{*}{$\mathrm{Pb}$} & 2011 & 42 & 1.29 & 0.42 & 1.18 & $0.70-2.59$ \\
\hline & 2014 & 43 & 1.42 & 0.34 & 1.34 & $0.89-2.69$ \\
\hline & 2018 & 42 & 1.01 & 0.24 & 0.96 & $0.70-1.80$ \\
\hline \multirow{3}{*}{$\mathrm{Zn}$} & 2011 & 42 & 3.61 & 1.09 & 3.20 & $2.20-6.40$ \\
\hline & 2014 & 43 & 4.48 & 1.73 & 4.30 & $2.70-13.00$ \\
\hline & 2018 & 42 & 3.39 & 1.44 & 2.95 & $1.90-10.70$ \\
\hline \multirow{3}{*}{$\mathrm{Ni}$} & 2011 & 42 & 0.64 & 0.18 & 0.60 & $0.40-1.10$ \\
\hline & 2014 & 43 & 0.70 & 0.16 & 0.70 & $0.50-1.10$ \\
\hline & 2018 & 42 & 0.61 & 0.19 & 0.60 & $0.30-1.30$ \\
\hline \multirow{3}{*}{ Co } & 2011 & 42 & 0.40 & 0.15 & 0.40 & $0.20-1.00$ \\
\hline & 2014 & 43 & 0.43 & 0.14 & 0.40 & $0.30-0.80$ \\
\hline & 2018 & 42 & 0.41 & 0.14 & 0.40 & $0.20-1.00$ \\
\hline \multirow{3}{*}{ Mn } & 2011 & 42 & 19.88 & 8.06 & 19.00 & $\begin{array}{c}10.00- \\
46.00\end{array}$ \\
\hline & 2014 & 43 & 23.70 & 12.43 & 20.00 & $\begin{array}{c}10.00- \\
66.00\end{array}$ \\
\hline & 2018 & 42 & 24.12 & 15.14 & 21.00 & $8.00-82.00$ \\
\hline \multirow{3}{*}{ As } & 2011 & 41 & 0.79 & 0.36 & 0.70 & $0.20-1.70$ \\
\hline & 2014 & 43 & 0.73 & 0.20 & 0.70 & $0.40-1.30$ \\
\hline & 2018 & 42 & 0.70 & 0.34 & 0.70 & $0.10-2.00$ \\
\hline \multirow{3}{*}{$\mathrm{Cr}$} & 2011 & 43 & 2.62 & 1.62 & 2.05 & $1.00-9.00$ \\
\hline & 2014 & 43 & 2.55 & 1.23 & 2.10 & $1.10-6.50$ \\
\hline & 2018 & 42 & 2.15 & 1.04 & 1.70 & $0.08-5.30$ \\
\hline \multirow{3}{*}{$\mathrm{Hg}(\mathrm{ppb})$} & 2011 & 8 & 8.25 & 1.98 & 7.5 & $6.00-12.00$ \\
\hline & 2014 & 18 & 8.89 & 2.42 & 9.00 & $5.00-13.00$ \\
\hline & 2018 & 6 & 8.33 & 2.42 & 8.00 & $5.00-11.00$ \\
\hline \multirow{3}{*}{$\mathrm{Fe}, \%$} & 2011 & 42 & 0.18 & 0.10 & 0.15 & $0.09-0.59$ \\
\hline & 2014 & 43 & 0.19 & 0.07 & 0.17 & $0.11-0.42$ \\
\hline & 2018 & 42 & 0.16 & 0.06 & 0.15 & $0.08-0.38$ \\
\hline \multirow{3}{*}{$\mathrm{Al}, \%$} & 2011 & 42 & 0.06 & 0.02 & 0.06 & $0.05-0.15$ \\
\hline & 2014 & 43 & 0.07 & 0.02 & 0.07 & $0.05-0.11$ \\
\hline & 2018 & 42 & 0.06 & 0.02 & 0.05 & $0.03-0.12$ \\
\hline \multirow{3}{*}{$\mathrm{Ca}, \%$} & 2011 & 42 & 0.36 & 0.25 & 0.28 & 0.09-1.19 \\
\hline & 2014 & 43 & 0.44 & 0.39 & 0.33 & $0.11-1.78$ \\
\hline & 2018 & 42 & 0.47 & 0.48 & 0.28 & $0.08-2.30$ \\
\hline \multirow{3}{*}{$\mathrm{Mg}, \%$} & 2011 & 42 & 0.07 & 0.03 & 0.07 & $0.03-0.17$ \\
\hline & 2014 & 43 & 0.08 & 0.05 & 0.07 & $0.03-0.24$ \\
\hline & 2018 & 42 & 0.08 & 0.05 & 0.08 & $0.03-0.30$ \\
\hline \multirow{3}{*}{$\mathrm{Ti}, \%$} & 2011 & 42 & 0.004 & 0.002 & 0.003 & $0.002-0.01$ \\
\hline & 2014 & 43 & 0.005 & 0.003 & 0.004 & $0.002-0.02$ \\
\hline & 2018 & 42 & 0.004 & 0.002 & 0.003 & $0.001-0.01$ \\
\hline
\end{tabular}



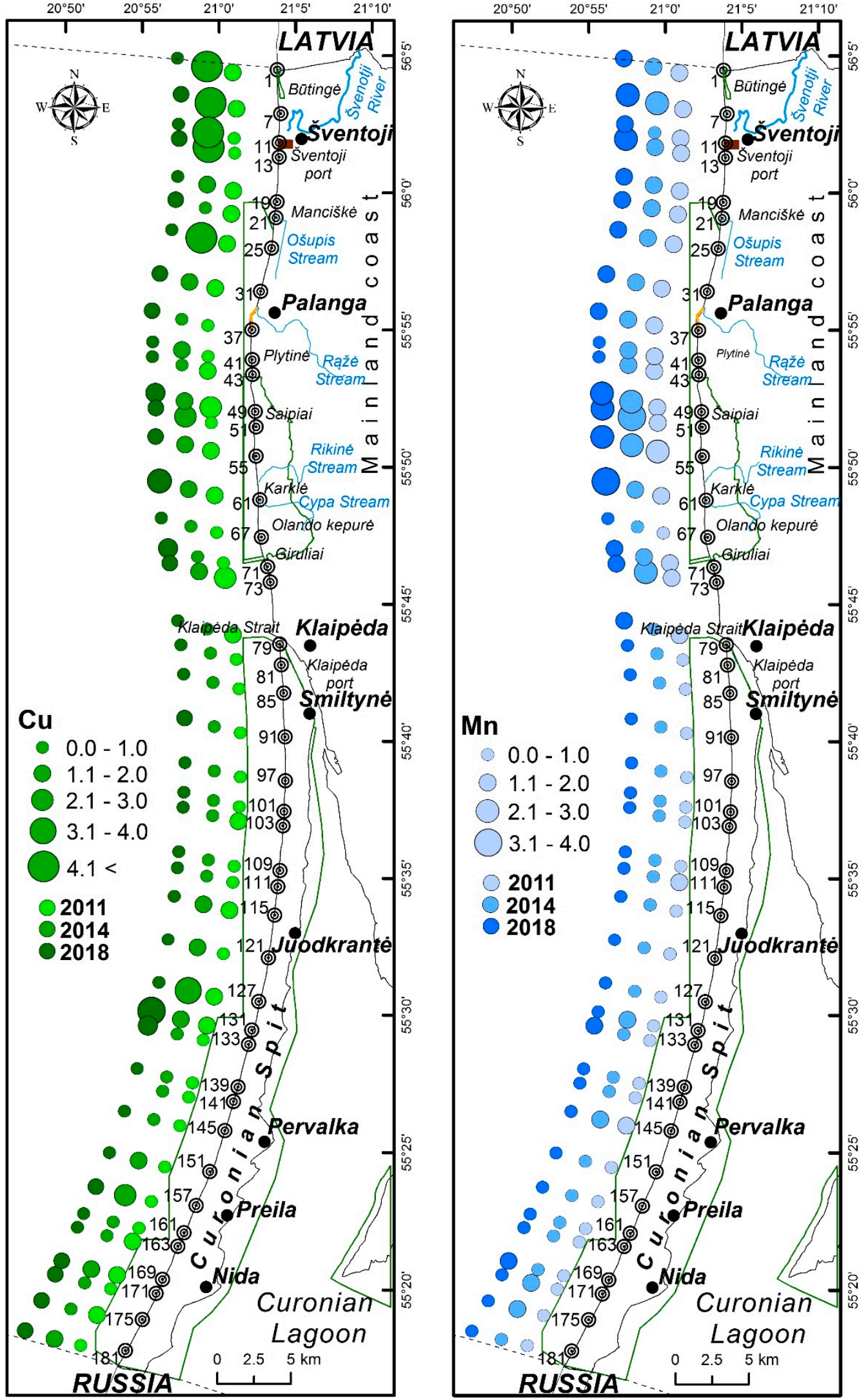

(a)

Figure 5. Cont. 


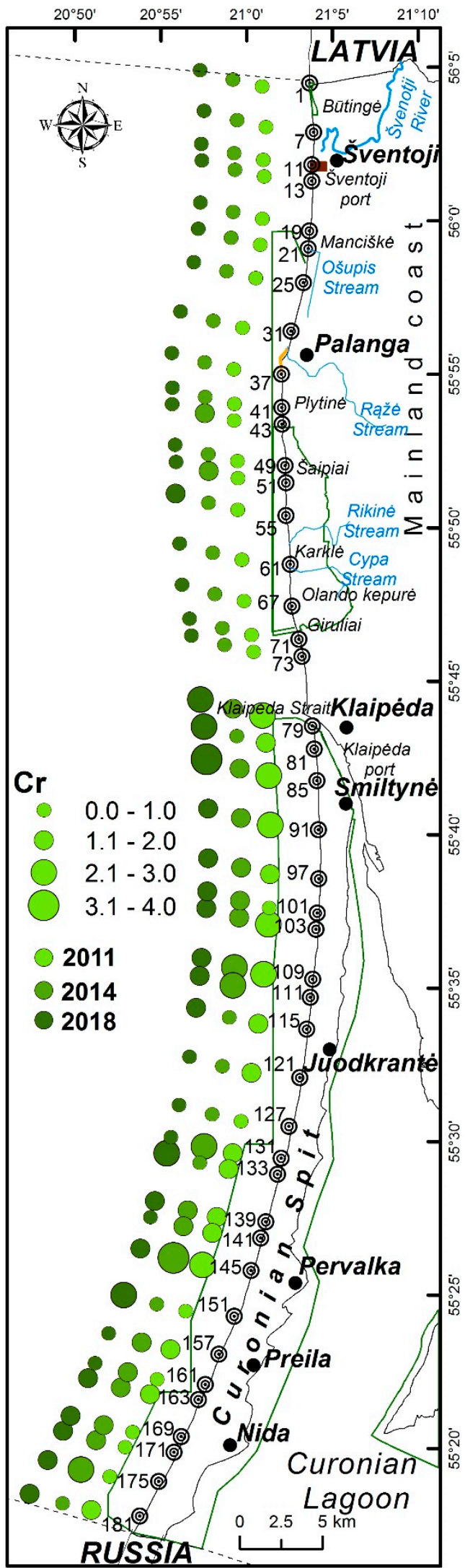

(b)

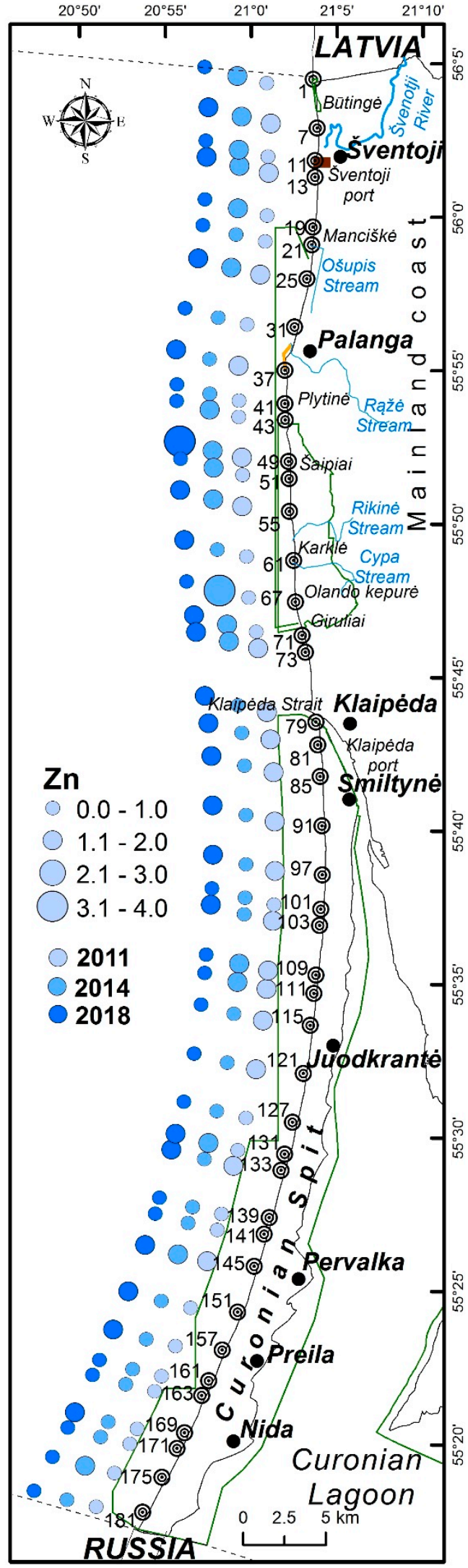

Figure 5. Cont. 

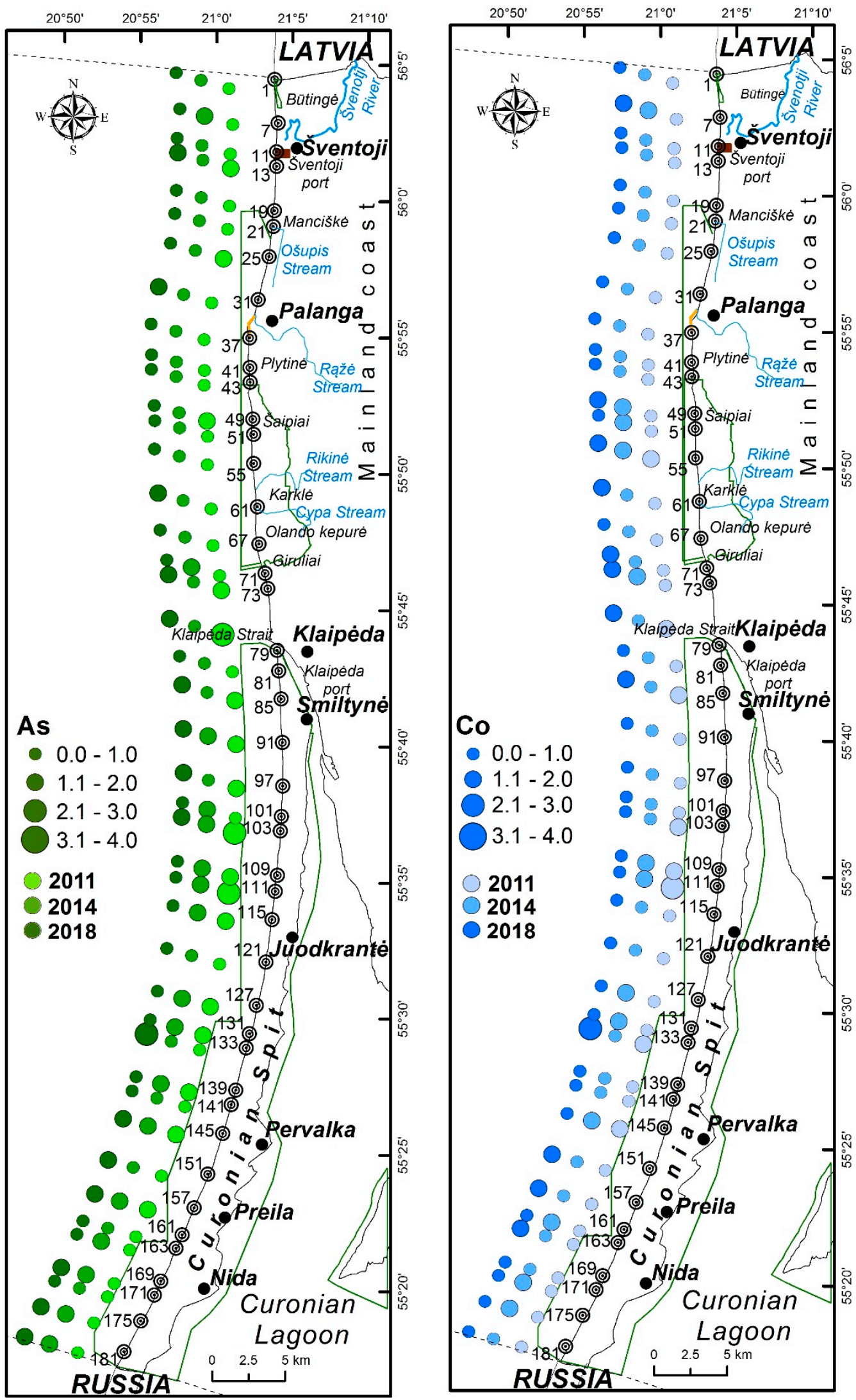

(c)

Figure 5. Cont. 

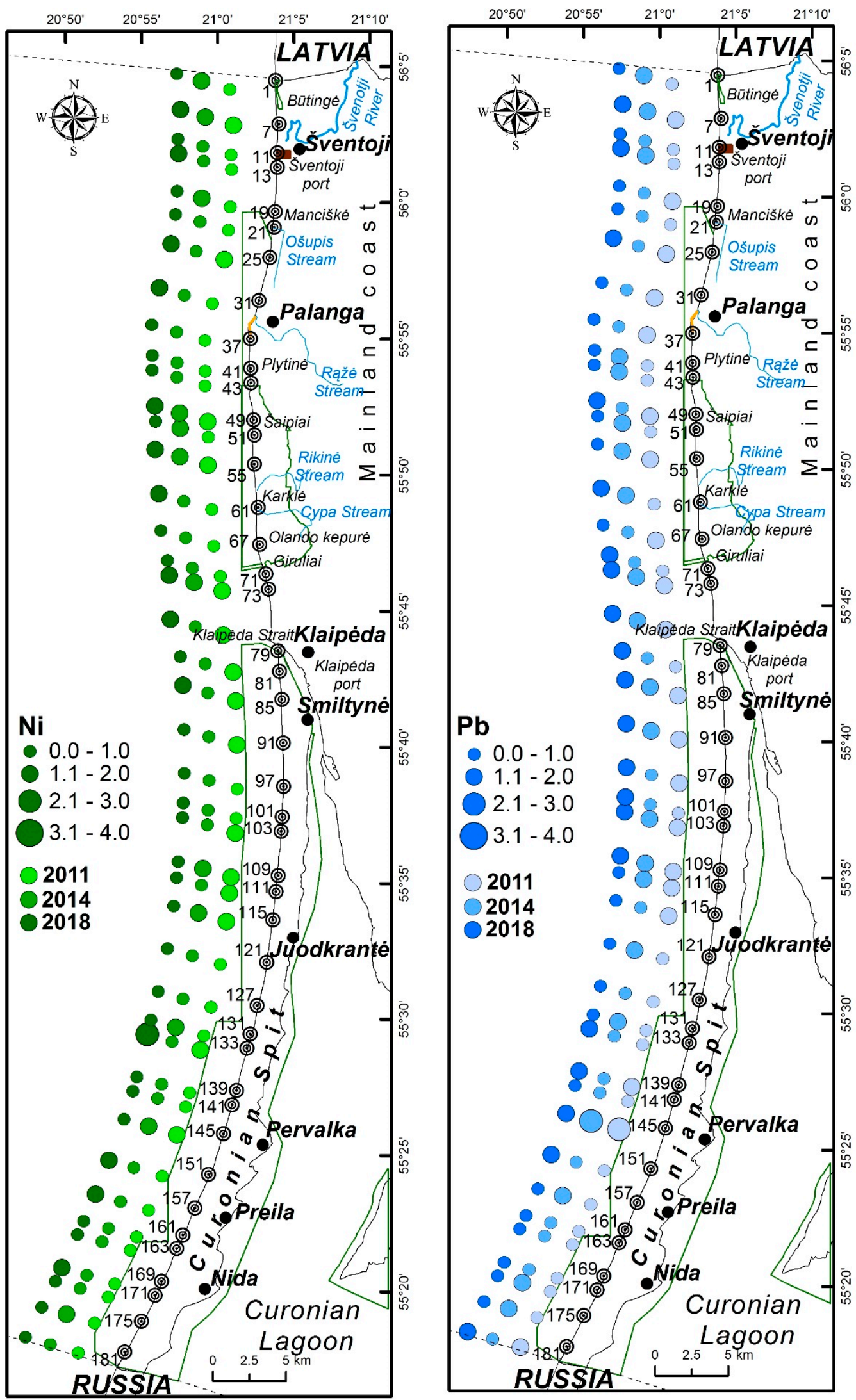

(d)

Figure 5. The distribution of concentration ratio $\left(K_{k}\right)$ of (a) $\mathrm{Cu}$ and $\mathrm{Mn},(\mathbf{b}) \mathrm{Cr}$ and $\mathrm{Zn},(\mathbf{c}) \mathrm{As}$ and $\mathrm{Co}$ and (d) $\mathrm{Ni}$ and $\mathrm{Pb}$ along the coast of the south-eastern Baltic Sea coast (Lithuania). 
The $\mathrm{Cu}$ concentration ratio exceeding or equal to 1.5 was estimated in five sites (1st, 7th, 49th, 55th, and 73rd) on the mainland coast in 2011; in 2014, in three sites (51st, 127th and 157th), and in 2018, in four sites (49th, 61st, 71st and 133rd). The Kk of Cu in 2014 exceeded four in five sites located near Šventoji (1st, 7th, 11th, 13th, and 25th) in the north part of the mainland coast and two sites on the Curonian Spit between Juodkrante and Pervalka (133rd and 141st sites) in 2018. The ratio Kk of Pb did not exceed 2.5 compared with $\mathrm{Cu}$. In 2011 and 2014, these ratios were higher than 1.5 only in the 145th site in Pervalka and in none of the sites in 2018.

The higher concentration ratios of Mn were estimated on the mainland coast opposite to $\mathrm{Cr}$. In all analysed years, higher Mn concentration ratios were estimated in the cliff area (49th-55th). Higher Mn ratio in 2014 and 2018 was also estimated in the site at 7th and also in the 13th and 73rd sites in 2018.

Zinc showed no clear pattern or difference between the mainland and Curonian Spit coasts (Figure 5). Overall, the highest $\mathrm{Zn}$ concentration ratios were determined on the mainland coast at the cliff area - in the 67th site in 2014 and the 49th in 2018. In 2011, the Zn concentration ratio was higher than 1.5 in eight sites (7th, 79th, 85th, 103rd-111th, and 145th), in 2014 in four sites (1st, 49th, 67th, and 71st) and in 2018, in six sites (7th, 49th, 61st, 71st, 85th, and 133rd).

Cobalt pattern differed from other elements because its concentration did not variate so much among the years. The concentration ratio exceeded 1.5 in 2011 only in two sites (111th and 145th); in 2014, in the sites 43rd, the 131st, and 145th; and in 2018, only in the 133rd site. The $\mathrm{Ni}$ as well as $\mathrm{Co}, \mathrm{Pb}$ did not show a clear pattern, its ratio exceeded $1.5 \mathrm{in}$ the 111th and 145th sites in 2011; 131st and 145th in 2014; and 55th, 61st, and 133rd sites in 2018.

To understand the overall distribution pattern of the analysed elements in 3 different years, we estimated and compared the mean of the concentration ratios $\left(K_{d}\right)$ in 2011, 2014, and 2018 (Figure 6). In 2011, slightly higher mean concentration ratios were indicated in the area where coastal erosion is active; $1 \mathrm{~km}$ northwards from Šventoji port (7th site), in the cliff areas (49th and 55th) and near the Klaipeda strait (73rd site). On the Curonian Spit coast, the distribution pattern of the mean concertation ratio is more pronounced than on the mainland coast, and increases northwards (highest peak at the 111th site).

In 2014, the trend of $K_{d}$ on the mainland coast distinguished from the pattern in 2011 and 2018. The mean concentration ratio was higher than 2 in 11 sites from 18 on the mainland coast and increased northwards. The mean concentration ratio exceeding 2 was determined in three sites located at the vicinity and northwards from the Šventoji port. On the Curonian Spit, the trend was opposite to the other years-the mean ratio slightly decreasing northwards.

In 2018, on the mainland coast, the estimated $K_{d}$ ratio values tend to decrease northwards, the highest values were determined in the cliff area (49th and 61st sites), and only in three sites was higher compared to previous years (49th, 61st, and 71st sites). On the Curonian Spit coast, the trend of the mean ratio increases northwards; however, it is mostly expressed from the 121st to 79th sites and from the 181st to 127th site, and the highest rations were determined in the section between Juodkrante and Pervalka (127th to 133rd sites and 141st site). In general, the trend is similar to 2011. 


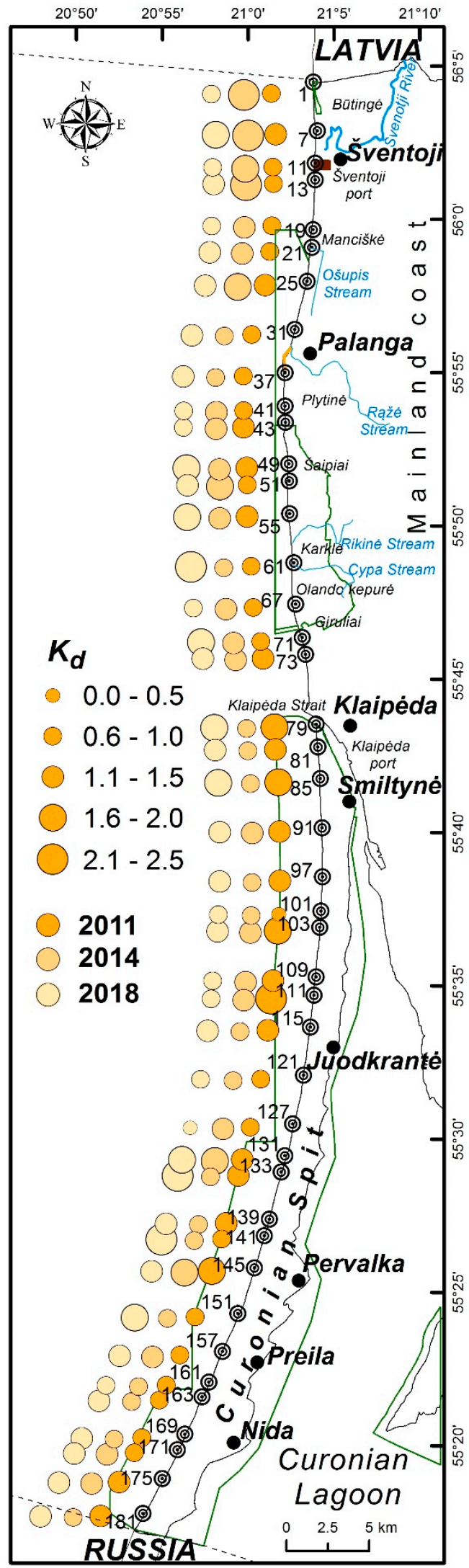

Figure 6. The distribution of the mean concentration ratio $\left(K_{d}\right)$ of all analysed trace elements along the south-eastern Baltic Sea coast (Lithuania). 


\subsection{Correlation Analysis}

The correlation analysis of trace elements and lithological and geomorphological factors showed that $\mathrm{Cu}$ content tends to accumulate in beach sediments where erosion processes are active as in 2011. In addition, it is depended on the sorting of the sediments $(r=0.40)$ (Table 2$)$ and was lower in the well-sorted sediments and negatively correlated with beach volume. The copper concentration positively correlated with the MS values in 2011 and $2014(r=0.59$ and $r=0.46)$.

Table 2. Pearson's correlation coefficient between trace metals and mean grain size $(\mathrm{d}, \mathrm{mm})$, sorting coefficient $\left(S_{o}\right)$, beach sediment volume $(Q, \mathrm{~m} 3 / \mathrm{m})$, and magnetic susceptibility (MS, $\mu \mathrm{SI})$.

\begin{tabular}{|c|c|c|c|c|c|c|c|c|c|c|c|c|}
\hline & \multicolumn{4}{|c|}{2011} & \multicolumn{4}{|c|}{2014} & \multicolumn{4}{|c|}{2018} \\
\hline Var & $d$ & So & $Q$ & MS & $d$ & So & $Q$ & MS & $d$ & So & $Q$ & MS \\
\hline $\mathrm{Cu}$ & 0.14 & $0.40^{* *}$ & $-0.31 *$ & $0.59 * *$ & 0.00 & 0.05 & -0.1 & $0.46^{* *}$ & 0.23 & 0.12 & -0.18 & 0.16 \\
\hline $\mathrm{Pb}$ & -0.07 & 0.09 & 0.19 & 0.26 & 0.16 & 0.00 & -0.1 & 0.24 & 0.38 * & 0.29 & 0.06 & $0.33^{*}$ \\
\hline $\mathrm{Zn}$ & -0.14 & 0.12 & 0.29 & 0.12 & 0.13 & 0.03 & -0.22 & $0.45^{* *}$ & 0.28 & 0.26 & -0.02 & $0.35^{*}$ \\
\hline $\mathrm{Ni}$ & -0.08 & 0.1 & 0.22 & 0.29 & 0.34 * & 0.23 & -0.27 & 0.23 & $0.59 * *$ & $0.48^{* *}$ & -0.27 & $0.31 *$ \\
\hline Co & -0.09 & -0.06 & 0.27 & 0.04 & $0.39 * *$ & $0.32 *$ & -0.14 & 0.23 & 0.68 ** & $0.47^{* *}$ & -0.16 & $0.33^{*}$ \\
\hline $\mathrm{Mn}$ & -0.19 & $0.38 *$ & $-0.46^{* *}$ & $0.79 * *$ & 0.27 & 0.24 & $-0.45^{* *}$ & $0.83^{* *}$ & 0.39 * & 0.25 & $-0.45^{* *}$ & $0.36^{*}$ \\
\hline As & -0.19 & -0.2 & $0.49 * *$ & -0.16 & 0.26 & 0.14 & 0.12 & -0.28 & $0.45^{* *}$ & 0.34 * & 0.04 & 0.22 \\
\hline $\mathrm{Cr}$ & -0.23 & -0.3 & $0.47^{* *}$ & -0.2 & -0.11 & -0.14 & 0.19 & -0.3 & -0.07 & -0.11 & $0.39 *$ & 0.04 \\
\hline$d$ & 1 & $0.41^{* *}$ & 0.04 & 0.07 & 1 & $0.79 * *$ & -0.12 & 0.13 & 1 & $0.64^{* *}$ & $-0.43^{* *}$ & $0.35 *$ \\
\hline So & $0.41^{* *}$ & 1 & -0.27 & $0.52^{* *}$ & $0.79 * *$ & 1 & -0.05 & 0.1 & $0.64^{* *}$ & 1 & -0.2 & 0.27 \\
\hline$Q$ & 0.04 & -0.27 & 1 & $-0.41^{* *}$ & -0.12 & -0.05 & 1 & -0.28 & $-0.43^{* *}$ & -0.2 & 1 & $-0.39 *$ \\
\hline MS & 0.07 & $0.52 * *$ & $-0.41^{* *}$ & 1 & 0.13 & 0.1 & -0.28 & 1 & $0.35 *$ & 0.27 & $-0.39 *$ & 1 \\
\hline
\end{tabular}

${ }^{* *}$ Correlation is significant at the 0.01 level (2-tailed). ${ }^{*}$ Correlation is significant at the 0.05 level (2-tailed).

The manganese content in all analysed years negatively correlated with beach sediment volume $(r=-0.46, \mathrm{r}=-0.45$, and $r=-0.45)$ and positively correlated with MS values $(r=0.79, r=0.83$, and $r=0.36)$. In 2011, the Mn concentration positively correlated $(r=0.38)$ with the sorting coefficient and in 2018 with grain size $(r=0.39)$. The zinc concentration positively correlated with MS values in 2014 and 2018 ( $r=0.45$ and $r=0.33)$. In 2011, the concentration positively correlated with beach sand volume $(r=0.49)$. In 2018, the As content positively correlated with grain size and sorting coefficient $(r=0.45$ and $r=0.34)$.

The grain size positively correlated with sorting coefficient in all investigated years; in 2018, grain size also positively correlated with MS values and negatively with beach volume (Table 2). In 2011, the sorting coefficient of beach sediments positively correlated with MS values. The measured beach volume negatively correlated with MS values in all years, but only in 2014 and 2018 it was statistically significant.

\subsection{Multivariate Analysis}

The PCA analysis was used to reduce the number of analysed variables and to identify the different factors that controlled the distribution of the elements in the beach sediments. For further analysis, we added macroelements as, $\mathrm{Al}, \mathrm{Ca}, \mathrm{Fe}, \mathrm{Mg}$, and $\mathrm{Ti}$, which helped to explain the origin of the trace elements. The results present principal components whose eigenvalues were above 1.

The PCA analysis of 3 years data revealed that there are two dominant groups of elements that are defined by the eigenvalues and the correlation coefficients (Figure 7). In 2011, three components were extracted, the first group (PC1) Fe-Co-Al-Cr-Ni-Zn-As$\mathrm{Pb}$ (explains $52.2 \%$ of the total variance with the highest eigenvalue 6.8 ), second (PC2) $\mathrm{Mn}-\mathrm{Ca}-\mathrm{Mg}-\mathrm{Ti}$ (eigenvalue 3.4; explains $26.2 \%$ of the total variance), and third (PC3) $\mathrm{Cu}$ (eigenvalue 1.27; explains 9.7\%). In 2014, only two components were extracted, the first group consisting of the following elements $\mathrm{Fe}-\mathrm{Co}-\mathrm{Ni}-\mathrm{Cr}-\mathrm{As}-\mathrm{Al}-\mathrm{Pb}$ (eigenvalue 5.3; explains $40.9 \%$ of the total variance) and second $\mathrm{Mn}-\mathrm{Ca}-\mathrm{Mg}-\mathrm{Ti}$ (eigenvalue 4.2 ; explains $32.3 \%$ of the total variance). In 2018, the element distribution between groups was similar as in other years- $\mathrm{PC1}$ : $\mathrm{Fe}-\mathrm{Pb}-\mathrm{As}-\mathrm{Co}-\mathrm{Cr}-\mathrm{Ni}-\mathrm{Al}$ (eigenvalue 5.2; explains $40.3 \%$ of the 
total variance), $\mathrm{PC} 2 \mathrm{Mn}-\mathrm{Ca}-\mathrm{Mg}-\mathrm{Ti}-\mathrm{Ni}-\mathrm{Al}$ (eigenvalue 4.7 ; explains $36.3 \%$ of the total variance), and PC3: $\mathrm{Cu}$ (eigenvalue 1.12; CV 8.6\% of the total variance).
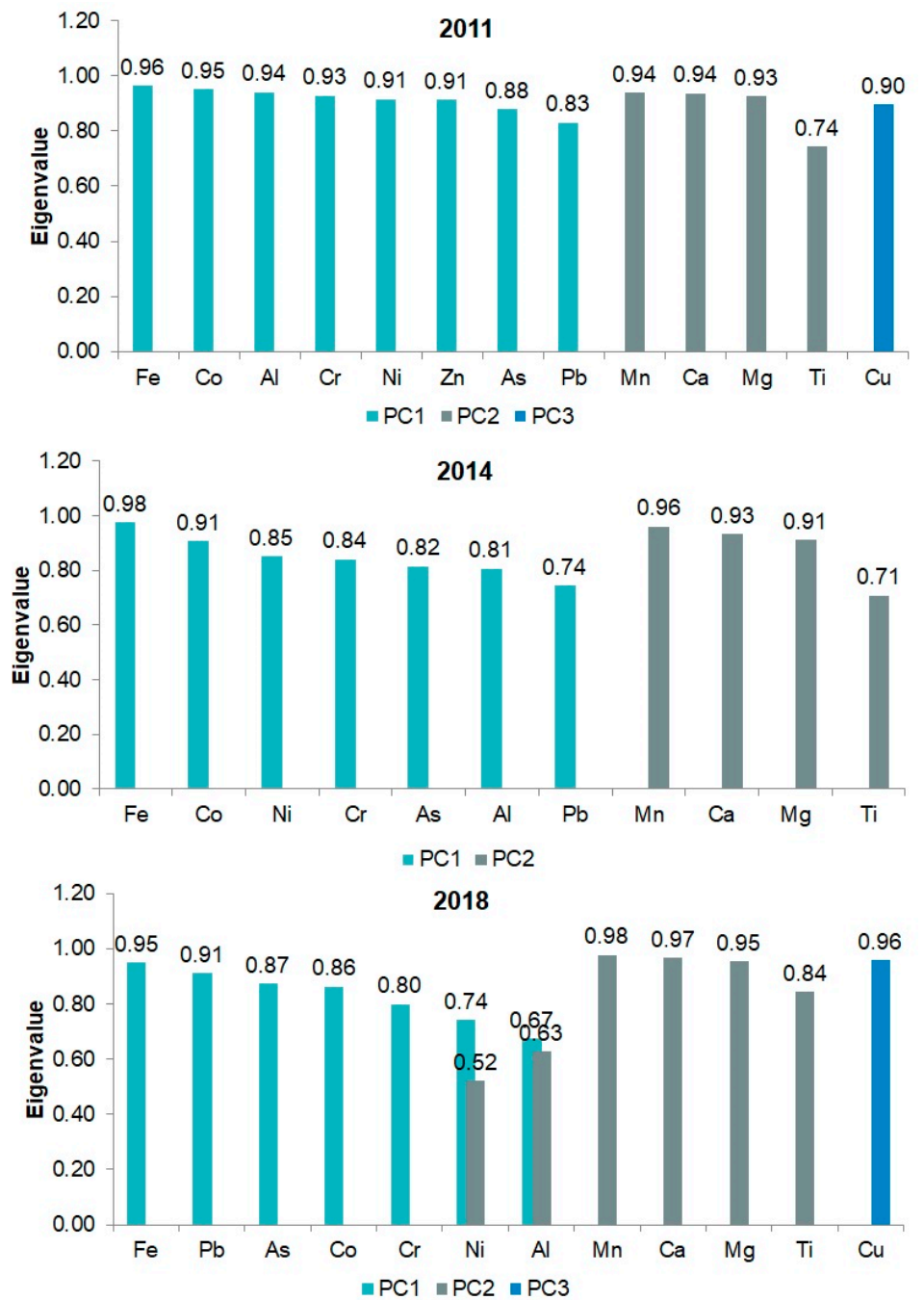

Figure 7. The loadings of analysed elements in different component groups after principal component analysis (Varimax rotation) in beach sediments of south-eastern Baltic Sea coast (Lithuania) in 2011, 2014, and 2018.

The PCA results showed that the elements from the first component group in 2011, 2014, and 2018 dominated in the Curonian Spit. The second group described sediments from the mainland coast (Figure 8). 


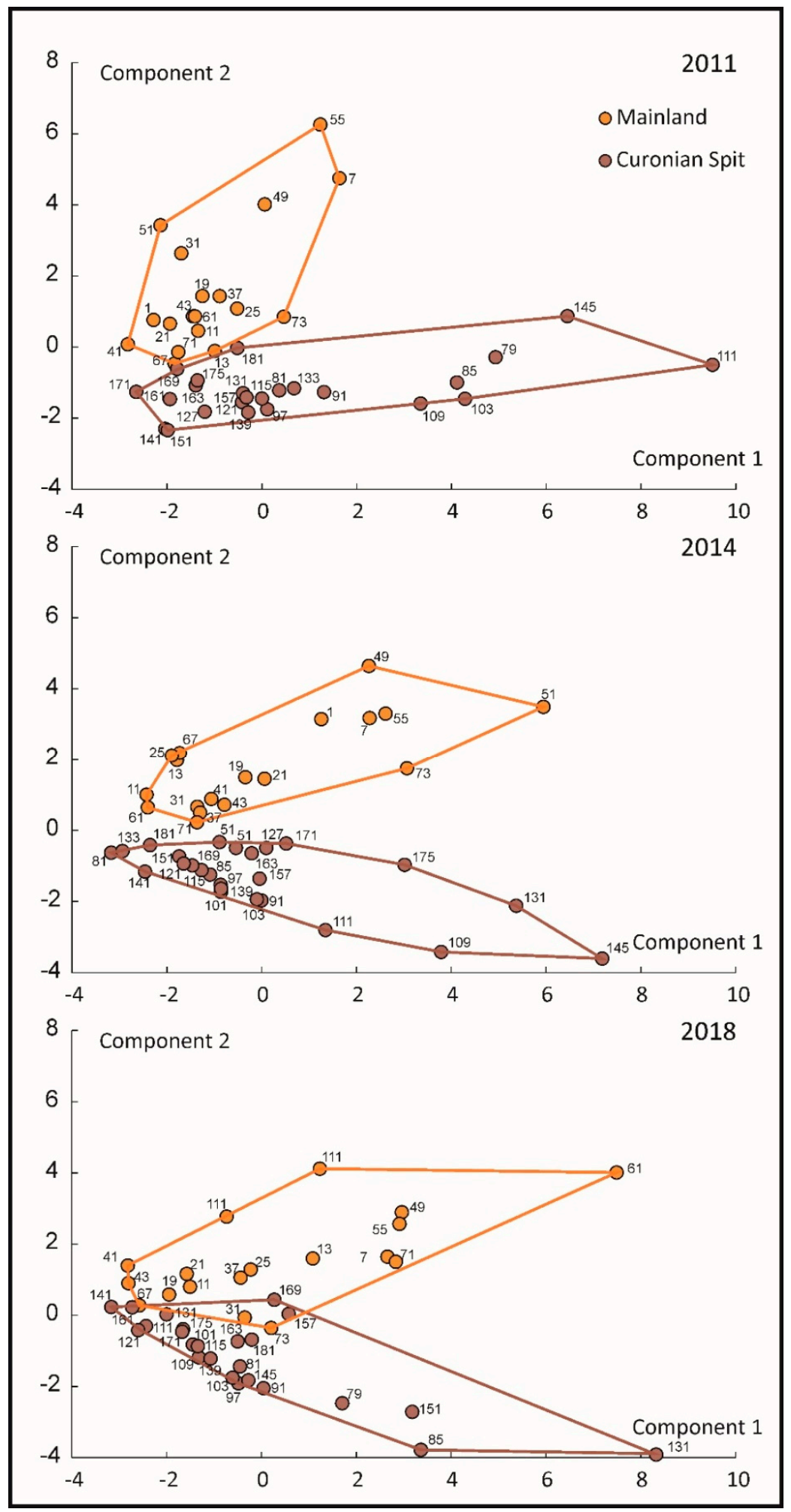

Figure 8. Principal component analysis after normalized varimax rotation, and factorial scores showed according to geographical location (Curonian Spit and mainland coast) in 2011, 2014, and 2018.

\section{Discussion}

It was found out that the trace element concentrations of beach sediments depend on the coastal processes and nonsignificantly varied among years, except for $\mathrm{Cu}$ and $\mathrm{Zn}$ in 2014. The $\mathrm{Mn}$ and $\mathrm{Cr}$ showed a clear distribution pattern along the coast during the years. 
Manganese concentration ratio was higher on the mainland coast, and it tended slightly to decrease northwards. The $\mathrm{Cr}$ concentration ratio was higher in Curonian Spit and increased at the distal end of it where the unloading of the sediments is active. These tendencies indicate that the alongshore sediment transport play a significant role in the distribution of the elements along the coast. The decrease in grain size in the north direction shows that the accumulation processes are conditioned by alongshore sediment transport directed from south to north (Figure 2). The measured amounts of beach sediment volume agree with these statements. Poorly sorted sediments were found in anthropogenically affected sections of the coast (Būtingè, Šventoji, Palanga, and Klaipèda) and in places where the sand grain size depends on the geological framework (Juodkrantè-Pervalka stretch).

The higher Mn concentration was determined in the sites with higher heavy mineral content and with a reduced beach sediment volume. Finer light mineral fractions such as quartz, feldspar, and muscovite mica are usually washed away, and the fine but heavier particles related to heavy minerals co-occur with coarser quartz particles [35,61]. Manganese according to the PCA analysis is associated with the second component group-carbonates ( $\mathrm{Ca}$ and $\mathrm{Mg}$ ), and this association remained during the investigation years. The dominance of carbonates can be explained by the deposits of detrital dolomite and biogenic calcite found on the mainland coast $[21,36]$. The greatest source of calcite and dolomite was found at Klaipeda and gradually decreased towards the south of Palanga [21]. The area southward from Klaipeda strait is less abundant in calcite [21].

The Mn distribution pattern also showed that its main source is at the moraine cliff area (Šaipiai-Olando kepurè). Its concentration increased during the years probably due to more active erosion on the mainland coast. Carbonate rocks also tend to form compounds with cations of divalent metals such as $\mathrm{Cu}, \mathrm{Zn}, \mathrm{Mn}, \mathrm{Sr}, \mathrm{Pb}$, etc. [54]. The $\mathrm{Zn}$ pattern shows that its concentration was also the highest close to the moraine cliff area. In addition, enlarged Zn concentration in 2014 and 2018 relates to higher heavy mineral content. The results indicated that its concentration is also linked to the erosion processes. The PCA analysis revealed that $\mathrm{Zn}$ concentration in 2011 is associated with sediments from the Curonian Spit, while in 2018 and 2014, there was no concrete association with any of groups. In 2014, the content of $\mathrm{Zn}$ was significantly higher than in other investigated years. This suggests that there might be additional sources besides natural ones. The cliff area (49th-61st sites) 30 years ago was an active military zone [75], which also could have affected sediments resulting in higher content of $\mathrm{Zn}$. The trace elements emitted in the past could migrate into deeper layers and in erosive areas could re-enter the environment after storms [76]. The $\mathrm{Zn}, \mathrm{Mn}$, and $\mathrm{Cu}$ content is higher in the 71st and 73rd sites, which overlap with the dumping sites of the sediments dredged from the Klaipeda Strait (Figure 1). The dredged sediments are more enriched with trace elements than beach sediments [53].

Higher than average MS values are associated with an increase in heavy minerals, whose content depends on the geological framework, which could enhance after a storm [26]. On the distal end of Curonian Spit the sediment accumulation prevail due to sediments delivered by the alongshore sediment transport [27,57]. The Curonian Spit coast beaches are enriched with glauconite (greensand) originating from Neogene-Paleogene deposits from the Sambian Peninsula [27,48]. The trace metals tend to attach to clay particles such as glauconite, mica, and biotite, which are transported northwards and unload at the distal end of the spit $[21,48,50,77-79]$. This relation is confirmed by the PCA analysis results, it means $\mathrm{Cr}$ together with $\mathrm{Pb}, \mathrm{Ni}, \mathrm{Co}$, and $\mathrm{As}$ in all analysed years form a group of metals associated with $\mathrm{Al}$ and $\mathrm{Fe}(\mathrm{Pb}-\mathrm{Ni}-\mathrm{Co}-\mathrm{Fe}-\mathrm{As}-\mathrm{Cr}-\mathrm{Al})$ which constitute the composition of glauconite [80]. Therefore, despite the sediments are enriched in trace elements in this part of the spit, they are characterised by decreased MS values as a result of coverage with quartz sand from aeolian processes.

As declared previously, the positive correlation with grain size and MS value indicated the coastal erosion. However, on the Curonian Spit, there is no active erosion [12,81]. The only anomaly of coarse sand in the Curonian Spit is located near Juodkranté-Pervalka site. The long-term sediment grain-size study recorded the relict origin of the anomaly 
and general stability of coastal sections of the spit [12]. This is in line with our lithological analysis. The concentration of analysed elements was determined higher in this area especially in 2011 and 2014 at 145th site and in 2018 at 131rd-133th sites. Since these coast stretches of the Curonian Spit were also richer in heavy minerals, this could cause the higher concentration of elements [82]. The correlation analysis revealed relationship related to greater elements' concentration ( $\mathrm{Ni}$ and $\mathrm{Co}$ in 2014 and $\mathrm{Ni}, \mathrm{Co}, \mathrm{Pb}$, and As in 2018) in coarser beach sands.

In 2014, the analysed trace elements' content was higher than the concentrations determined in 2011 and 2018, specifically, the loading of $\mathrm{Cu}$ and $\mathrm{Zn}$ on the mainland coast. Similar to $\mathrm{Zn}$, the increased $\mathrm{Cu}$ concentration was associated with a higher content of heavy minerals only in 2011 and 2014. However, in 2014, Cu concentration significantly increased to the north of Šventoji Port that could suggest an anthropogenic source. In this case, the sediments' geochemistry could be affected by the Šventoji Port reconstruction in 2011-2012, when the bottom sediments were dredged from the entrance channel and stored on the beach [83], and later washed away after the storm "Xaver" in 2013. The bottom surface sediments in the Šventoji Port basin were enriched with $\mathrm{Pb}, \mathrm{Ni}, \mathrm{Cu}$, and $\mathrm{Zn}$ [84]. Additionally, the sediment in the north of Šventoji has greater absorption capacity due to the peat layer, which is exposed after stormy weather event [85].

The study has some limitations regarding ambiguous evidence of the anthropogenic impact. Our hypotheses are based on literature analysis. For example, our results show anomalies of trace elements southwards from Juodkrante on the Curonian Spit coast. These anomalies could be also consequences of the local fisheries activities due to possible oil leakage or accidents at a D6 oil platform, coastal protection construction of tires, or cement block at the Sambian Peninsula in the provenance region of the spit sediments $[27,67]$.

\section{Conclusions}

Distribution analysis of the trace elements on the south-eastern Baltic Sea coast indicated that the concentration mainly depended on the coastal processes (alongshore sediment transport, coastal erosion, and sediment accumulation). The differences in trace element concentrations and composition between the Curonian Spit and the mainland coast indicated various sources. The trace metal concentrations on the mainland coast mainly increased in the areas with active erosion processes when heavy minerals were exposed. On the Curonian Spit, trace element anomalies are associated with relict sands. The elements such as $\mathrm{Cr}$ and as tend to accumulate at the distal end of the spit where sediments most actively accumulate. Since the coast is a dynamic environment, the elements' concentration at the same sites may vary from year to year. For example, in 1 year, severe weather events may lead to more intense coast erosion. In another year, when calm weather is favourable for accretion, these sediments might be covered with fine quartz sand or reworked and redeposited. However, our results showed that beach sediment geochemical composition remains invariable in space and time. The anomalous concentration of $\mathrm{Cu}$ and $\mathrm{Zn}$ on the coast indicated the possible anthropogenic impact on sediment geochemical composition (such as former military activities and beach nourishment with dredged sediments from the port).

Author Contributions: Conceptualization, D.K. and D.P.; methodology, D.K., D.P. and D.J. and G.Ž.; formal analysis, D.J., D.P., and G.Ž.; investigation, D.K., D.P., and A.D.; data curation, D.K., A.D., D.J. and D.P.; writing—original draft preparation, D.K.; writing—review and editing, D.P., D.J., A.D. and G.Ž.; visualization, D.P. and D.K. All authors have read and agreed to the published version of the manuscript.

Funding: This research is a part of a project (duration 2017-2021) funded from the public budget of the Republic of Lithuania.

Institutional Review Board Statement: Not applicable.

Informed Consent Statement: Not applicable. 
Acknowledgments: The authors would like to thank the reviewers for their constructive comments, which helped improve our manuscript. Authors are also very thankful for student Anna CichonPupienis for fine tuning the manuscript.

Conflicts of Interest: The authors declare no conflict of interest.

\section{References}

1. Bełdowska, M.; Bolałek, J.; Bojakowska, I.; Burska, D.; Cyberski, J.; Dudzińska-Huczuk, B.; Ebbing, J.; Falkowska, L.; Graca, B.; Kramarska, R.; et al. Geochemistry of Baltic Sea Surface Sediments; Uścinowicz, S., Ed.; Polish Geological Institute-National Research Institute: Warsaw, Poland, 2011.

2. Harris, L.; Nel, R.; Holness, S.; Schoeman, D. Quantifying Cumulative Threats to Sandy Beach Ecosystems: A Tool to Guide Ecosystem-Based Management beyond Coastal Reserves. Ocean Coast. Manag. 2015, 110, 12-24. [CrossRef]

3. Trojanowski, J.; Bigus, K.; Trojanowska, C. Differences of Chemical Components in Beaches Sediments with Dissimilar Anthropopressure. Balt. Coast. Zo. J. Ecol. Prot. Coastline 2011, 15, 109-126.

4. $\quad$ Bird, E.C.F. Coastal Geomorphology: An Introduction; Wiley: Hoboken, NJ, USA, 2000.

5. Song, Y.; Choi, M.S. Assessment of Heavy Metal Contamination in Sediments along the Coast of South Korea Using Cs-Normalized Background Concentrations. Mar. Pollut. Bull. 2017, 117, 532-537. [CrossRef] [PubMed]

6. Ohta, T. Geochemistry of Jurassic to Earliest Cretaceous Deposits in the Nagato Basin, SW Japan: Implication of Factor Analysis to Sorting Effects and Provenance Signatures. Sediment. Geol. 2004, 171, 159-180. [CrossRef]

7. Weltje, G.J. Ternary Sandstone Composition and Provenance: An Evaluation of the Dickinson Model. Geol. Soc. Lond. Spec. Publ. 2006, 264, 79-99. [CrossRef]

8. Lee, Y.I. Geochemistry of Shales of the Upper Cretaceous Hayang Group, SE Korea: Implications for Provenance and Source Weathering at an Active Continental Margin. Sediment. Geol. 2009, 215, 1-12. [CrossRef]

9. Cox, R.; Lowe, D.R.; Cullers, R.L. The Influence of Sediment Recycling and Basement Composition on Evolution of Mudrock Chemistry in the Southwestern United States. Geochim. Cosmochim. Acta 1995, 59, 2919-2940. [CrossRef]

10. Abdel-Karim, A.A.M.; Zaid, S.M.; Moustafa, M.I.; Barakat, M.G. Mineralogy, Chemistry and Radioactivity of the Heavy Minerals in the Black Sands, along the Northern Coast of Egypt. J. Afr. Earth Sci. 2016, 123, 10-20. [CrossRef]

11. Armstrong-Altrin, J.S.; Lee, Y.I.; Kasper-Zubillaga, J.J.; Carranza-Edwards, A.; Garcia, D.; Eby, G.N.; Balaram, V.; Cruz-Ortiz, N.L. Geochemistry of Beach Sands along the Western Gulf of Mexico, Mexico: Implication for Provenance. Geochemistry 2012, 72, 345-362. [CrossRef]

12. Jarmalavičius, D.; Žilinskas, G.; Pupienis, D. Geologic Framework as a Factor Controlling Coastal Morphometry and Dynamics. Curonian Spit, Lithuania. Int. J. Sediment Res. 2017, 32, 597-603. [CrossRef]

13. Chavadi, V.C.; Hegde, V.S. A Note on the Textural Variation of Beach Sediments in the Vicinity of Gangavali River Mouth near Ankola, West Coast of India. Mahasagar 1989, 22, 89-98.

14. Carranza-Edwards, A.; Kasper-Zubillaga, J.J.; Rosales-Hoz, L.; Morales-dela Garza, E.A.; Lozano-Santa Cruz, R. Beach Sand Composition and Provenance in a Sector of the Southwestern Mexican Pacific. Rev. Mex. Cienc. Geol. 2009, 26, $433-447$.

15. Barnard, P.L.; Foxgrover, A.C.; Elias, E.P.L.; Erikson, L.H.; Hein, J.R.; McGann, M.; Mizell, K.; Rosenbauer, R.J.; Swarzenski, P.W.; Takesue, R.K.; et al. Integration of Bed Characteristics, Geochemical Tracers, Current Measurements, and Numerical Modeling for Assessing the Provenance of Beach Sand in the San Francisco Bay Coastal System. Mar. Geol. 2013, 345, 181-206. [CrossRef]

16. Armstrong-Altrin, J.S.; Nagarajan, R.; Lee, Y.I.; Kasper-Zubillaga, J.J.; Córdoba-Saldaña, L.P. Geochemistry of Sands along the San Nicolás and San Carlos Beaches, Gulf of California, Mexico: Implications for Provenance and Tectonic Setting. Turk. J. Earth Sci. 2014, 23, 533-558. [CrossRef]

17. Armstrong-Altrin, J.S.; Nagarajan, R.; Balaram, V.; Natalhy-Pineda, O. Petrography and Geochemistry of Sands from the Chachalacas and Veracruz Beach Areas, Western Gulf of Mexico, Mexico: Constraints on Provenance and Tectonic Setting. J. South Am. Earth Sci. 2015, 64, 199-216. [CrossRef]

18. Dickinson, W.R.; Suczek, C.A. Plate Tectonics and Sandstone Compositions1. Am. Assoc. Pet. Geol. Bull. 1979, 63, $2164-2182$. [CrossRef]

19. Basu, A.; Blanchard, D.P.; Brannon, J. Rare Earth Elements in the Sedimentary Cycle: A Pilot Study of the First Leg. Sedimentology 1986, 29, 737-742. [CrossRef]

20. Kasper-Zubillaga, J.J.; Dickinson, W.W. Discriminating Depositional Environments of Sands from Modern Source Terranes Using Modal Analysis. Sediment. Geol. 2001, 143, 149-167. [CrossRef]

21. Kairyte, M.; Stevens, R.L.; Trimonis, E. Provenance of Silt and Clay within Sandy Deposits of the Lithuanian Coastal Zone (Baltic Sea). Mar. Geol. 2005, 218, 97-112. [CrossRef]

22. Saha, S.; Banerjee, S.; Burley, S.D.; Ghosh, A.; Saraswati, P.K. The Influence of Flood Basaltic Source Terrains on the Efficiency of Tectonic Setting Discrimination Diagrams: An Example from the Gulf of Khambhat, Western India. Sediment. Geol. 2010, 228, 1-13. [CrossRef]

23. Kurian, N.P.; Prakash, T.N.; Jose, F.; Black, K.P. Hydrodynamic Processes and Heavy Mineral Deposits of the Southwest Coast, India. J. Coast. Res. 2001, 154-163.

24. Kovaleva, O.; Chubarenko, B.; Pupienis, D. Grain Size Variability as an Indicator of Sediment Transport Alongshore the Curonian Spit (South-Eastern Baltic Sea). Baltica 2016, 29, 145-155. [CrossRef] 
25. Morrone, C.; De Rosa, R.; Le Pera, E.; Marsaglia, K.M. Provenance of Volcaniclastic Beach Sand in a Magmatic-Arc Setting: An Example from Lipari Island (Aeolian Archipelago, Tyrrhenian Sea). Geol. Mag. 2017, 154, 804-828. [CrossRef]

26. Pupienis, D.; Buynevich, I.V.; Bitinas, A. Distribution and Significance of Heavy-Mineral Concentrations along the Southeast Baltic Sea Coast. J. Coast. Res. 2011, SI64, 1984-1988.

27. Pupienis, D.; Buynevich, I.; Ryabchuk, D.; Jarmalavičius, D.; Žilinskas, G.; Fedorovič, J.; Kovaleva, O.; Sergeev, A.; Cichon-Pupienis, A. Spatial Patterns in Heavy-Mineral Concentrations along the Curonian Spit Coast, Southeastern Baltic Sea. Estuar. Coast. Shelf Sci. 2017, 195, 41-50. [CrossRef]

28. Caredda, A.M.; Cristini, A.; Ferrara, C.; Lobina, M.F.; Baroli, M. Distribution of Heavy Metals in the Piscinas Beach Sediments (SW Sardinia, Italy). Environ. Geol. 1999, 38, 91-100. [CrossRef]

29. Vidinha, J.M.; Rocha, F.; Silva, E.; Patinha, C.; Andrade, C. Geochemical Beach Sediments Studies-A Contribution to a Standard Definition Useful for Public Health. J. Coast. Res. 2009, 2009, 905-908.

30. Jarmalavičius, D.; Pupienis, D.; Buynevich, I.V.; Žilinskas, G.; Fedorovič, J. Aeolian Sand Differentiation along the Curonian Spit Coast, Baltic Sea, Lithuania. Coast. Sediments 2015, 2015, 1-10. [CrossRef]

31. Yalcin, F.; Nyamsari, D.G.; Paksu, E.; Yalcin, M.G. Statistical Assessment of Heavy Metal Distribution and Contamination of Beach Sands of Antalya-Turkey: An Approach to the Multivariate Analysis Techniques. Filomat 2016, 30, 945-952. [CrossRef]

32. Nordstrom, K.F.; Lampe, R.; Vandemark, L.M. Reestablishing Naturally Functioning Dunes on Developed Coasts. An Int. J. Decis. Makers Sci. Environ. Audit. 2000, 25, 37-51. [CrossRef]

33. Ariza, E.; Jiménez, J.A.; Sardá, R. An Interdisciplinary Analysis of Beach Management in the Catalan Coast (North-Western Mediterranean). Coast. Manag. 2012, 40, 442-459. [CrossRef]

34. Defeo, O.; McLachlan, A.; Schoeman, D.S.; Schlacher, T.A.; Dugan, J.; Jones, A.; Lastra, M.; Scapini, F. Threats to Sandy Beach Ecosystems: A Review. Estuar. Coast. Shelf Sci. 2009, 81, 1-12. [CrossRef]

35. Hanamgond, P.T.; Gawali, P.B.; Lakshmi, B.V.; Babu, J.L.V.M.; Deendayalan, K. Sediment Texture and Geochemistry of Beaches between Redi-Vengurla, Sindhudurg, West Coast of India. J. Coast. Res. 2017, 33, 1135-1147. [CrossRef]

36. Yalcin, M.G. Heavy Mineral Distribution as Related to Environmental Conditions for Modern Beach Sediments from the Susanoglu (Atakent, Mersin, Turkey). Environ. Geol. 2009, 58, 119-129. [CrossRef]

37. Sun, W.; Sang, L.; Jiang, B. Trace Metals in Sediments and Aquatic Plants from the Xiangiang River, China. J. Soils Sediments 2012, 12, 1649-1657. [CrossRef]

38. Ra, K.; Kim, E.-S.; Kim, K.-T.; Kim, J.-K.; Lee, J.-M.; Choi, J.-Y. Assessment of Heavy Metal Contamination and Its Ecological Risk in the Surface Sediments along the Coast of Korea. J. Coast. Res. 2013, 65, 105-110. [CrossRef]

39. Jonathan, M.P.; Roy, P.D.; Thangadurai, N.; Srinivasalu, S.; Rodríguez-Espinosa, P.F.; Sarkar, S.K.; Lakshumanan, C.; NavarreteLópez, M.; Muñoz-Sevilla, N.P. Metal Concentrations in Water and Sediments from Tourist Beaches of Acapulco, Mexico. Mar. Pollut. Bull. 2011, 62, 845-850. [CrossRef]

40. Nagarajan, R.; Jonathan, M.P.; Roy, P.D.; Wai-Hwa, L.; Prasanna, M.V.; Sarkar, S.K.; Navarrete-López, M. Metal Concentrations in Sediments from Tourist Beaches of Miri City, Sarawak, Malaysia (Borneo Island). Mar. Pollut. Bull. 2013, 73, 369-373. [CrossRef]

41. Vetrimurugan, E.; Shruti, V.C.; Jonathan, M.P.; Roy, P.D.; Kunene, N.W.; Villegas, L.E.C. Metal Concentration in the Tourist Beaches of South Durban: An Industrial Hub of South Africa. Mar. Pollut. Bull. 2017, 117, 538-546. [CrossRef]

42. Díaz Rizo, O.; Buzón González, F.; Arado López, J.O. Assessment of Ni, Cu, Zn and Pb Levels in Beach and Dune Sands from Havana Resorts, Cuba. Mar. Pollut. Bull. 2015, 100, 571-576. [CrossRef]

43. Bramha, S.N.; Mohanty, A.K.; Satpathy, K.K.; Kanagasabapathy, K.V.; Panigrahi, S.; Samantara, M.K.; Prasad, M.V.R. Heavy Metal Content in the Beach Sediment with Respect to Contamination Levels and Sediment Quality Guidelines: A Study at Kalpakkam Coast, Southeast Coast of India. Environ. Earth Sci. 2014, 72, 4463-4472. [CrossRef]

44. Dobaradaran, S.; Schmidt, T.C.; Nabipour, I.; Khajeahmadi, N.; Tajbakhsh, S.; Saeedi, R.; Javad Mohammadi, M.; Keshtkar, M.; Khorsand, M.; Faraji Ghasemi, F. Characterization of Plastic Debris and Association of Metals with Microplastics in Coastline Sediment along the Persian Gulf. Waste Manag. 2018, 78, 649-658. [CrossRef] [PubMed]

45. Retama, I.; Jonathan, M.P.; Roy, P.D.; Rodríguez-Espinosa, P.F.; Nagarajan, R.; Sarkar, S.K.; Morales-García, S.S.; Muñoz-Sevilla, N.P. Metal Concentrations in Sediments from Tourist Beaches of Huatulco, Oaxaca, Mexico: An Evaluation of Post-Easter Week Vacation. Environ. Earth Sci. 2016, 75, 1-10. [CrossRef]

46. Nour, H.E.; El-Sorogy, A.S. Distribution and Enrichment of Heavy Metals in Sabratha Coastal Sediments, Mediterranean Sea, Libya. J. Afr. Earth Sci. 2017, 134, 222-229. [CrossRef]

47. Vetrimurugan, E.; Shruti, V.C.; Jonathan, M.P.; Roy, P.D.; Rawlins, B.K.; Rivera-Rivera, D.M. Metals and Their Ecological Impact on Beach Sediments near the Marine Protected Sites of Sodwana Bay and St. Lucia, South Africa. Mar. Pollut. Bull. $2018,127$. [CrossRef]

48. Krek, A.; Krechik, V.; Danchenkov, A.; Krek, E. Pollution of the Sediments of the Coastal Zone of the Sambia Peninsula and the Curonian Spit (Southeastern Baltic Sea). PeerJ 2018, 2018, 1-17. [CrossRef]

49. Bigus, K.; Astel, A.; Niedzielski, P. Seasonal Distribution of Metals in Vertical and Horizontal Profiles of Sheltered and Exposed Beaches on Polish Coast. Mar. Pollut. Bull. 2016, 106, 347-359. [CrossRef]

50. Stauskaitè, R. Mineralogical Composition of Sand from the Baltic Sea Coastal Stretch between Šventoji- Jantarnoe (Palvininkai). Proc. Sci. Acad. Lith. Ser. B 1962, 4, 83-105. 
51. Jarmalavičius, D.; Satkūnas, J.; Žilinskas, G.; Pupienis, D. The Influence of Coastal Morphology on Wind Dynamics. Est. J. Earth Sci. 2012, 61, 120-130. [CrossRef]

52. Radzevicius, R. Main Trends in Accumulation of Trace Elements from Surface Sediments of the Baltic Sea (Lithuanian Waters). Baltica 2002, 15, 63-73.

53. Remeikaitè-Nikienè, N.; Garnaga-Budrè, G.; Lujanienė, G.; Jokšas, K.; Stankevičius, A.; Malejevas, V.; Barisevičiūtè, R. Distribution of Metals and Extent of Contamination in Sediments from the South-Eastern Baltic Sea (Lithuanian Zone). Oceanologia 2018, 60, 193-206. [CrossRef]

54. Galkus, A.; Jokšas, K. Nuosédinè Medžiaga Tranzitinèje Akvasistemoje=: Sedimentary Material in the Transitional Aquasystem; Geografijos Inst: Vilnius, Lithuania, 1997.

55. Pustelnikovas, O. Geochemistry of Sediments of the Curonian Lagoon (Baltic Sea); Inst. of Geography: Vilnius, Lithuania, 1998.

56. Pupienis, D.; Buynevich, I.V.; Jarmalavičius, D.; Žilinskas, G.; Fedorovič, J. Regional Distribution of Heavy-Mineral Concentrations along the Curonian Spit Coast of Lithuania. J. Coast. Res. 2013, 65, 1844-1849. [CrossRef]

57. Žilinskas, G.; Jarmalavičius, D.; Pupienis, D. The Influence of Natural and Anthropogenic Factors on Grain Size Distribution along the Southeastern Baltic Spits. Geol. Q. 2018, 62, 375-384. [CrossRef]

58. Žilinskas, G.; Janušaitè, R.; Jarmalavičius, D.; Pupienis, D. The Impact of Klaipèda Port Entrance Channel Dredging on the Dynamics of Coastal Zone, Lithuania. Oceanologia 2020, 62, 489-500. [CrossRef]

59. Blott, S.J.; Pye, K. Gradistat: A Grain Size Distribution and Statistics Package for the Analysis of Unconsolidated Sediments. Earth Surf. Process. Landforms 2001, 26, 1237-1248. [CrossRef]

60. Sandgren, P.; Snowball, I. Application of Mineral Magnetic Techniques to Paleolimnology BT-Tracking Environmental Change Using Lake Sediments: Physical and Geochemical Methods; Last, W.M., Smol, J.P., Eds.; Springer Netherlands: Dordrecht, The Netherlands, 2001; pp. 217-237. [CrossRef]

61. Hunt, C.P.; Moskowitz, B.M.; Banerjee, S.K. Magnetic Properties of Rocks and Minerals. In Rock Physics E Phase Relations; Wiley: Hoboken, NJ, USA, 1995; pp. 189-204. [CrossRef]

62. Dearing, J. Environmental Magnetic Susceptibility. In Using the Bartington MS2 System; Chi Publ: Kenilworth, UK, 1999 ; Volume 43.

63. Hatfield, R. Particle Size-Specific Magnetic Measurements as a Tool for Enhancing Our Understanding of the Bulk Magnetic Properties of Sediments. Minerals 2014, 4, 758-787. [CrossRef]

64. Eberhards, G.; Lapinskis, J.; Saltupe, B. Hurricane Erwin 2005 Coastal Erosion in Latvia. Baltica 2006, $19,10-19$.

65. Garnaga, G. Integrated Assessment of Pollution in the Baltic Sea. Ekologija 2012, 58, 331-355. [CrossRef]

66. Liaghati, T.; Preda, M.; Cox, M. Heavy Metal Distribution and Controlling Factors within Coastal Plain Sediments, Bells Creek Catchment, Southeast Queensland, Australia. Environ. Int. 2004, 29, 935-948. [CrossRef]

67. Krek, A.; Danchenkov, A.; Ulyanova, M.; Ryabchuk, D. Heavy Metals Contamination of the Sediments of the South-Eastern Baltic Sea: The Impact of Economic Development. Baltica 2019, 32, 51-62. [CrossRef]

68. Kadūnas, V. Technogenine Geochemija=Technogenic Geochemistry; Geology Institute: Vilnius, Lithuania, 1998.

69. Krek, A.; Ulyanova, M.; Koschavets, S. Influence of Land-Based Kaliningrad (Primorsky) Amber Mining on Coastal Zone. Mar. Pollut. Bull. 2018, 131, 1-9. [CrossRef] [PubMed]

70. Hakanson, L. An Ecological Risk Index for Aquatic Pollution Control.a Sedimentological Approach. Water Res. 1980, 14, 975-1001. [CrossRef]

71. Abrahim, G.; Parker, R. Assessment of Heavy Metal Enrichment Factors and the Degree of Contamination in Marine Sediments from Tamaki Estuary, Auckland, New Zealand. Int. J. Devoted to Prog. Use Monit. Data Assess. Environ. Risks to Man Environ. 2008, 136, 227-238. [CrossRef] [PubMed]

72. Turekian, K.K.; Wedephol, K.H. Distribution of the Elements in Some Major Units of the Earth's Crust. GSA Bull. 1961, 72, 175-192. [CrossRef]

73. Taylor, S.R. Abundance of Chemical Elements in the Continental Crust: A New Table. Geochim. Cosmochim. Acta 1964, 28, 1273-1285. [CrossRef]

74. Putys, P. Geocheminiai Tyrimai Šilutès Plote. = Geochemical Analysis in Šilutè Area; Lithuanian Geological Survey: Vilnius, Lithuania, 1999.

75. Baubinas, R.; Taminskas, J. Karine Gamtonauda Lietuvoje Sovietmečiu: Ekologinès Pasekmès =: Military Nature Use in Lithuania in the Soviet Years: Ecological Consequences; Geografijos Institutas: Vilnius, Lithuania, 1998.

76. Bełdowska, M.; Jędruch, A.; Łęczyński, L.; Saniewska, D.; Kwasigroch, U. Coastal Erosion as a Source of Mercury into the Marine Environment along the Polish Baltic Shore. Environ. Sci. Pollut. Res. 2016, 23, 16372-16382. [CrossRef]

77. Gudelis, V.; Kirlys, V.; Stauskaitè, R.; Jankevičiūtè-Močiekienè, S. Dynamics of Swash (Wave Run-up) and the Lithodynamics of Sand Beaches on the Lithuanian Coast of the Baltic Sea. In O динамике отмелого песчаного берега (по наблюдениям н $a$ побережьеВосточной Балтики)//Развитие морских берегов в условиях колебательных движений земной коры.= Оn the Dynamics of a Shallow Sandy Coast (According to Observations on the Coast of the Eastern Baltic)//Development of Sea Coast in a Vibrational Motion of the Earth's Crust; Aibulatov, N.A., Dolotov, Y.S., Orlova, G.A., Yurkevich, M.G., Orvik, K.K., Orlova, G.A., Eds.; Valgus: Tallinn, Estonia, 1966; p. 240. Available online: https://erb.nlib.ee/?kid=13831161\&fbclid=IwAR0Pd6ZUD7 7efQgwik5WFKezhWUxmVrHafO_gzNLtbjCh2dubRkkiYkJOY4 (accessed on 25 January 2021).

78. Apanaviciute, J.; Simkevicius, P. Distribution of Heavy Minerals in Surficial Bottom Sediments of the Nida—Klaipëda Mapping Area in the Baltic Sea. Geologija 2001, 33, 29-39. 
79. Sergeev, A. The History of Geological Development of the Curonian Spit in the Holocene and Modern Lithodynamic Processes in the Coastal Zone; A.P. Karpinsky Russian Geological Research Institute: St. Petersberg, Russia, 2015. (In Russian)

80. Thompson, G.R.; Hower, J. The Mineralogy of Glauconite. Clays Clay Miner. 1975, 23, 289-300. [CrossRef]

81. Jarmalavicius, D.; Pupienis, D.; Zilinskas, G.; Janusaite, R.; Karaliunas, V. Beach-Foredune Sediment Budget Response to Sea Level Fluctuation. Curonian Spit, Lithuania. Water 2020, 12, 583. [CrossRef]

82. Salomons, W.; Förstner, U. Metals in the Hydrocycle; Springer Science \& Business Media: Berlin/Heidelberg, Germany, 1984.

83. Jokšas, K.; Galkus, A.; Stakènaite,, R.; Lagunavičienè, L. Heavy Metals in Bottom Sediments of Water System Transformed by Human Activity: Šventoji Port, Lithuania. In Proceedings of the 3rd International Conference in Lithuania "Metals in the Environment", Vilnius, Lithua, 22-23 May 2006; pp. 56-58. [CrossRef]

84. Galkus, A.; Joksas, K.; Stakeniene, R.; Lagunaviciene, L. Heavy Metal Contamination of Harbor Bottom Sediments. Pol. J. Environ. Stud. 2012, 21, 1583-1594.

85. Bitinas, A.; Damušytè, A.; Žaromskis, R.; Gulbinskas, S.; Žilinskas, G.; Jarmalavičius, D. Baltijos jūros Lietuvos krantu geologinis atlasas. Geol. Akiračiai 2005, 2, 14-22. 